"A direct, efficient method for the preparation of siRNAs containing ribo-like North bicyclo[3.1.0]hexane pseudosugars" Terrazas, M., Aviñó, A., Siddiqui, M., Marquez, V., Eritja, R. Org. Lett., 13(11), 2888-2891 (2011).

PMID: 21553811, doi: 10.1021/ol200909j

\title{
A direct, efficient method for the preparation of siRNAs containing ribo-like North bicyclo[3.1.0]hexane pseudosugars
}

\author{
Montserrat Terrazas, $†$ Anna Aviñó, $†$ Maqbool A. Siddiqui,ł \\ Victor E. Marquez, ${ }^{*} \neq$ and Ramon Eritja*, $\dagger$
}

Institute for Research in Biomedicine (IRB Barcelona), Networking Center on Bioengineering, Biomaterials and Nanomedicine (CIBER-BBN), and Institute for Advanced Chemistry of Catalonia (IQAC), Spanish Research Council (CSIC), Cluster Building, Baldiri i Reixac 10, E-08028 Barcelona, Spain, and Laboratory of Chemical Biology, Center for Cancer Research, National Cancer Institute at Frederick, Frederick, MD 21702 USA.

Email Address: recgma@cid.csic.es

Abstract:
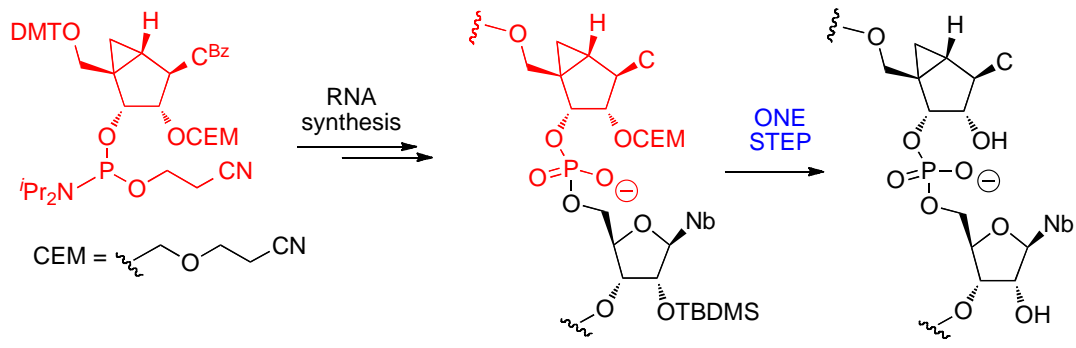

An efficient method for the preparation of siRNAs modified with ribo-like North bicyclo[3.1.0]hexane pseudosugars is described. The combined use of 2'-O-(2cyanoethoxymethyl) (CEM) and 2'-O-TBDMS protection was successfully employed for RNA synthesis with the added advantage that both groups were efficiently removed in a single step. The resulting North ribo-methanocarba-modified siRNAs are compatible with the intracellular RNAi machinery and can mediate specific degradation of target mRNA.

Nucleotide analogues that exhibit the North-type sugar puckering1 and possess the overall A-RNA-type conformation have attracted much interest in the field of RNA interference (RNAi) therapy.2 RNAi is a sequence-specific RNA silencing mechanism3 triggered by double-stranded RNA or short interfering RNA molecules (siRNA), which are formed by a sense and a guide strand. 4 Within the cells, an RNA-induced silencing complex (RISC) 5 unwinds the siRNA duplex and uses the guide strand as a template to find the complementary target mRNA, 6 an event that induces the endonucleolytic cleavage of the mRNA7 and prevents its translation into protein. For efficient gene silencing to take place, the guide siRNA:mRNA duplex must adopt an A-type helical structure. 8 In order to fulfill these requirements and to improve target-binding affinity, several North-locked nucleotide building blocks have been designed, synthesized, and 
incorporated into siRNAs.9 Examples are 2'-O-alkylated RNAs,8b,10 2'-fluoroRNAs, 8b,10a,11 and Locked Nucleic Acids (LNA); the latter containing a methylene bridge between the $2^{\prime}$ oxygen and the 4 ' carbon. 12 In particular, LNAs have been widely explored and it is well known that LNA-modified siRNAs efficiently induce the RNAi process and increase the thermodynamic and serum stability of RNA duplexes to a great extent. 13

Another candidate for introducing new features into siRNAs without perturbing the Atype helical structure they require for activity is the North-locked form of nucleotide analogues based on a carbocyclic bicyclo[3.1.0]hexane system [methanocarba (MC) nucleosides]. Preliminary studies on the effect of North 2'-deoxy-MC nucleosides on the RNAi process have shown that these pseudonucleosides are accepted by the RNAi machinery.14 However, the effect of a hydroxyl group at the 2' position of any of the modified sugars, or the carbocyclic pseudosugar, on the RNAi process has never been investigated. The design and synthesis of North ribo-MC nucleosides (Figure 1) has been reported.15 Nevertheless, these derivatives have never been incorporated into RNA strands.
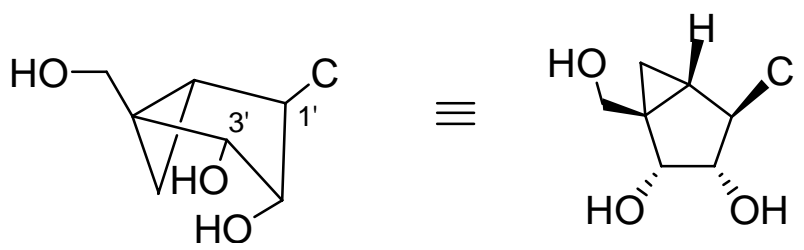

Figure 1. North ribo-methanocarba cytidine monomer $(\mathrm{CN})$

Herein we describe a synthetic strategy for the preparation of conveniently 2'-Oprotected phosphoramidite of North ribo-MC cytidine (CN) (Figure 1). We also describe its incorporation into mixed 2'-O-protected RNA strands and the removal of the 2'-O-protecting groups of the RNAs in a single step. This approach permits an easy access to the preparation of North ribo-MC cytidine-modified siRNAs with potential therapeutic applications.

An important challenge in the preparation of RNA strands modified with North ribo$\mathrm{MC}$ is the protection of the 2'-OH group of the pseudoribose. Preliminary studies on the reactivity of the 2'-OH group of North ribo-MC cytidine carried out in our group have shown that the 3 '-OH is much more reactive than the 2 '-OH group (data not shown). Thus, in contrast to what has been reported for a great number of nucleoside derivatives, 16 the direct protection of the 2'-OH group of 5'-O-protected ribo-MC cytidine derivatives with a free 3'-hydroxyl group becomes a serious problem. The attempted strategy was to employ a 3',5'-O-disiloxan diprotected intermediate with a free 2'-OH group (1, Scheme 1). Our first try involved the protection of the free 2'-OH in 1 with a benzoyl group. However, this route was abandoned due to the rapid migration of the 2'-O-benzoyl from the 2'-OH to the 3'-OH after deprotection.

A wide variety of 2'-O-protecting groups have been developed for RNA synthesis.16,17 For example, fluoride-labile protecting groups such as tert-butyldimethylsilyl (TBDMS),17a [(triisopropylsilyl)oxy]methyl (TOM)17b and 2-cyanoethoxymethyl (CEM)17c groups, or the photo-labile [(2-nitrobenzyl)oxy]methyl group17d among others.16 TBDMS and TOM are popular 2'-OH protecting groups whose phosphoramidites are commercially available. We decided to use the cheaper 2'-OTBDMS-protected phosphoramidites of natural ribonucleosides for RNA synthesis. 
However, for the protection of the 2'-OH group of the 3',5'-O-disiloxan protected MC nucleoside 1, the fluoride-labile TBDMS and TOM groups had to be avoided since the disiloxane protecting group is also removed by a fluoride reagent like TBAF. To overcome these problems, the group of Wada et al. have found a way to prevent the removal of the CEM group during the removal of the disiloxan group of 3',5'-Odisiloxan-2'-O-CEM-protected nucleosides, by treatment with TBAF in the presence of AcOH.18

As for RNA synthesis, removal of the CEM group from fully 2'-O-CEM-protected RNA strands has been successfully achieved under aprotic conditions.19 In our search for a synthetic method that would allow ready cleavage of the 2'-O-protecting group of the MC nucleoside and the 2'-O-TBDMS protecting group of natural nucleosides from the final RNA product in only one step, we decided to focus on the CEM group.

Scheme 1. Preparation of 2'-O-CEM-protected ribo-MC cytidine building block

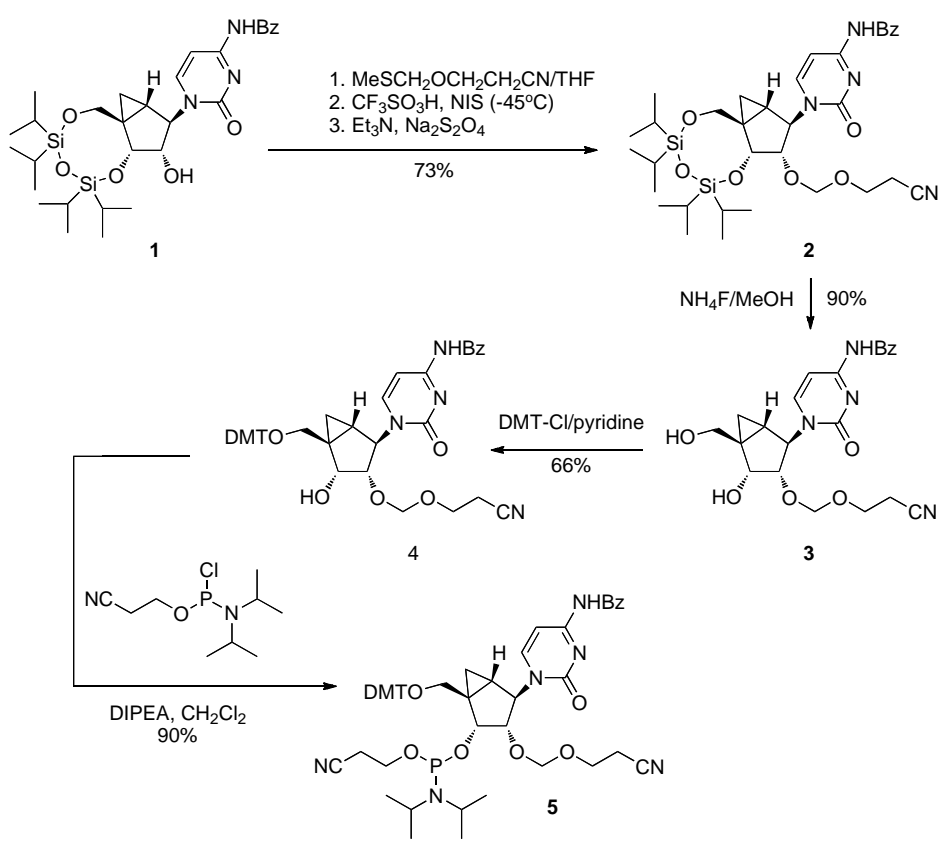

The synthesis of compound 1 is relatively straightforward and it is described in the supplementary section. As described in Scheme 1, compound 1 was treated with 2cyanoethyl methylthiomethyl ether to give the desired 2'-O-CEM-3',5'-O-disiloxanprotected derivative 2 in $73 \%$ yield. Following the fluoride-catalyzed removal of the disiloxan protecting group the desired 2'-O-CEM protected diol 3 was obtained in $90 \%$ yield. The $5^{\prime}$ hydroxyl group was then protected by a 4,4'-dimethoxytrityl group (DMT) and the resulting 5'-O-DMT-2'-O-CEM-protected nucleoside 4 was converted into the desired phosphoramidite (5).

With compound 5 at hand we proceeded to incorporate this nucleotide building block $(\mathrm{CN})$ into different positions in place of the natural ribocytidine along a 21-mer RNA guide strand that targets the Renilla luciferase mRNA by using a DNA/RNA synthesizer. The solid-phase synthesis was carried out on a 0.2 mol scale with a coupling time of $10 \mathrm{~min}$. For $\mathrm{CN}$-modified RNAs, $\mathrm{P}(\mathrm{III})$ to $\mathrm{P}(\mathrm{V})$ oxidation was performed with a solution of 10\% tert-butyl hydroperoxide in acetonitrile/water (96:4). Commercially available succinyl polystyrene functionalized with 5'-O-DMT-2'deoxythymidine was used as the solid support and tetrazole as the activator. 
Phosphoramidites of 2'-O-TBDMS protected natural ribonucleosides (A, U, G and C) were obtained from commercial sources. We prepared RNA guide strands containing no substitutions (6, wt), one $\mathrm{CN}$ substitution at position 8 (7) and two $\mathrm{CN}$ substitutions spaced-out along the guide strand at positions 8 and 15 (8). We also prepared the corresponding unmodified sense strand (Table 1).

After RNA synthesis, the DMT-on polystyrene solid support was treated with a mixture of $33 \%$ ammonia solution and ethanol $[3: 1(\mathrm{v} / \mathrm{v})]$ for $24 \mathrm{~h}$ at $35^{\circ} \mathrm{C} 16 \mathrm{c}$ for the cleavage from the polystyrene solid support and the removal of the phosphate-protecting and base-protecting groups. In the next step, the 2'-O-TBDMS protecting group of unmodified guide (6) and sense strands was completely removed by treatment with $1 \mathrm{M}$ $\mathrm{TBAF} / \mathrm{THF}$ for $12 \mathrm{~h}$.

Table 1. Sequences of RNAs and Tm data

1 3'-TTAAAAAGAGGAAGAAGUCUA (sense)

2 5'-UUUUUCUCCUUCUUCAGAUTT (guide, 6, wt) $\quad 67.6$

$3 \quad 5$ '-UUUUUCUCNCUUCUUCAGAUTT (guide, 7) 65.9

$4 \quad 5$ '-UUUUUCUCNCUUCUUCNAGAUTT (guide, 8) 64.5

$\mathrm{T}_{\mathrm{m}} \mathrm{s}$ were measured in $15 \mathrm{mM}$ HEPES-KOH (pH 7.4), $1 \mathrm{mM} \mathrm{MgCl} 2$ and $50 \mathrm{mM} \mathrm{KOAc.}$

For the removal of 2'-O-TBDMS and 2'-O-CEM protecting groups of RNAs 7 and 8, $10 \%$ n-propylamine and $1 \%$ of bis(2-mercaptoethyl) ether in $1 \mathrm{M}$ TBAF/THF was used instead of $1 \mathrm{M} \mathrm{TBAF/THF}$ to prevent formation of CEM adducts, a side reaction reported by Ohgi et al.14 These authors report complete removal of 2'-O-CEM protecting groups of fully 2'-O-CEM protected RNA strands after $6 \mathrm{~h}$ at r.t. Under these conditions, we obtained mixtures of 2'-O-protected and 2'-O-deprotected RNAs (as evaluated by HPLC). We increased the reaction time (to 12, 15 and $24 \mathrm{~h}$ ) and after shaking at room temperature for $24 \mathrm{~h}$, HPLC analysis of the crude oligo showed a single main peak corresponding to the fully deprotected product and only small amounts of shorter products (Figure 2A). Fully 2'-O-deprotected RNAs (6, 7, 8 and sense) were purified by reverse phase semi-preparative HPLC in the DMT-on mode. Finally, the DMT-on products were treated with $80 \% \mathrm{AcOH}$ solution to remove the DMT group and the de-protected products were desalted on NAP columns. The desired products were obtained in good overall yields (7, 58\%; 22 OD; 8, 35\%, 13 OD).
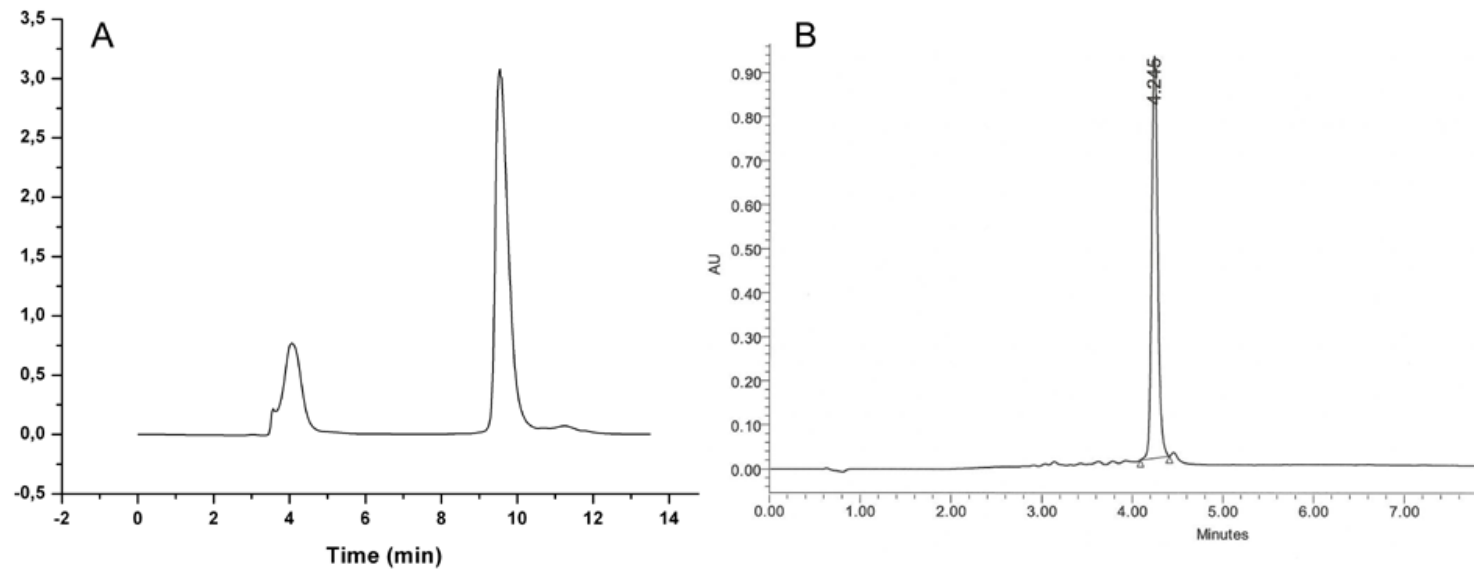

Figure 2. HPLC analysis of RNA 7. (A) Unpurified fully deprotected RNA 7. (B) Purified fully deprotected RNA 7. 
RNA strands 7 and 8 were treated with nuclease P1 and then alkaline phosphatase, and the digestion products were analyzed by HPLC. No modified ribonucleosides (2'-OCEM protected ribo-MC cytidine or 2'-O-TBDMS protected U, A, C and G) were observed; showing that complete removal of the CEM and TBDMS protecting groups and base-protecting groups was achieved.

Finally, in order to study the effect of the ribo North MC cytidine substitution on the RNA interference process, we carried out separate RNAi studies in SH-SY5Y cells with siRNA duplexes containing each of the modified guide strands (7 and 8), as well as with the unmodified (wt) guide RNA (6). Experiments were carried out in triplicate. The cells were first transfected with dual reporter plasmids that express Renilla luciferase (the target) and non-targeted firefly as an internal control. The effects of the different siRNAs on luciferase expression were evaluated using 26-0.03 nM siRNA concentrations in the cell media and measuring luciferase responses after $22 \mathrm{~h}$. The results show that the RNAi machinery is not impaired by the North MC riboC modification (Figure S27). The best results were obtained for siRNA containing one substitution in the guide strand (7), which showed activity comparable to that of wt siRNA (6). To confirm the specificity of the observed effects, sequence-scrambled siRNAs were used (Table S1). As expected, scrambled sequences gave no Renilla inhibition (Figure S27). Thermal denaturation studies suggested that the $\mathrm{CN}$ modification caused a slight destabilization of the siRNA duplex $\left(\mathrm{T}=-1.6{ }^{\circ} \mathrm{C}\right.$ per substitution; Table 1). However, such small destabilization did not significantly affect RNAi activity.

In conclusion, in this work we have reported an strategy for (i) the preparation of North ribo-MC nucleosides conveniently protected at the 2'-OH position, (ii) their incorporation into mixed 2'-O-protected RNA strands and (iii) the removal of the 2'-Oprotecting groups of the RNA in only one step. To the best of our knowledge, this is the first time that the synthesis and one-step de-protection of a 2'-O-TBDMS/2'-O-CEM oligoribonucleotides has been described.

Acknowledgment. This research was supported by the Spanish Ministry of Education (BFU2007-63287 and CTQ2010-20541-C03-01) and the Generalitat de Catalunya (2009/SGR/208) and the Instituto de Salud Carlos III. This work was funded in part by the Center for Cancer Research, National Cancer Institute, NIH. M. T. Acknowledges Juan de la Cierva contract (MICINN, Spain) for financial support.

$\uparrow$ IRB Barcelona.

+ National Cancer Institute at Frederick.

(1) Altona, C.; Sundaralingam, M. J. Am. Chem. Soc. 1973, 95, 2333.

(2) (a) Manoharan, M. Biochim. Biophys. Acta 1999, 1489, 117. (b) Freier, S. M.; Altmann, K. H. Nucleic Acids Res. 1997, 25, 4429.

(3) (a) Fire, A.; Xu, S.; Montgomery, M. K.; Kostas, S. A.; Driver, S. E.; Mello, C. C. Nature 1998, 391, 806. (b) Elbashir, S. M.; Harborth, J.; Lendeckel, W.; Yalcin, A.; Weber, K.; Tuschl, T. Nature 2001, 411, 494. (c) Bumcrot, D.; Manoharan, M.; Koteliansky, V.; Sah, D. W. Y. Nat. Chem. Biol. 2006, 2, 711.

(4) (a) Elbashir, S. M.; Lendeckel, W.; Tuschl, T. Genes Dev. 2001, 15, 188. (b) Elbashir, S. M.; Martinez, J.; Patkaniowska, A.; Lendeckel, W.; Tuschl, T. EMBO J. 2001, 20, 6877. (c) Tang, G.; Reinhart, B. J.; Bartel, D. P.; Zamore, P. D. Genes Dev. 2003, 17, 49. 
(5) (a) Hammond, S. M.; Bernstein, E.; Beach, D.; Hannon, G. J. Nature 2000, 404, 293. (b) Valencia-Sanchez, M. A.; Liu, J.; Hannon, G.J.; Parker, R. Genes Dev. 2006, $20,515$.

(6) Nykänen, A.; Haley, B.; Zamore, P. D. Cell 2001, 107, 309.

(7) (a) Meister, G.; Landthaler, M.; Patkaniowska, A.; Dorsett, Y.; Teng, G.; Tuschl, T. Mol. Cell 2004, 15, 185. (b) Matranga, C.; Tomari, Y.; Shin, C.; Bartel, D. P.; Zamore, P. D. Cell 2005, 123, 607. (c) Rand, T. A.; Petersen, S.; Du, F.; Wang, X. Cell 2005, $123,621$.

(8) (a) Chiu, Y.-L.; Rana, T. M. Mol. Cell 2002, 10, 549. (b) Chiu, Y.-L.; Rana, T. M. RNA 2003, 9, 1034.

(9) For a review, see: Watts, J. K.; Deleavey, G. F.; Damha, M. J. Drug Discov. Today $2008,13,842$.

(10) (a) Dowler, T.; Bergeron, D.; Tedeschi, A.-L.; Paquet, L.; Ferrari, N.; Damha, M. J. Nucleic Acids Res. 2006, 34, 1669. (b) Amarzguioui, M.; Holen, T.; Babaie, E.; Prydz, H. Nucleic Acids Res. 2003, 31, 589. (c) Czauderna, F.; Fechtner, M.; Dames, S.; Aygün, H.; Klippel, A.; Pronk, G. J.; Giese, K.; Kaufmann, J. Nucleic Acids Res. 2003, 31, 2705.

(11) Deleavey, G. F.; Watts, J. K.; Alain, T.; Robert, F.; Kalota, A.; Aishwarya, V.; Pelletier, J.; Gewirtz, A. M.; Sonenberg, N.; Damha, M. J. Nucleic Acids Res. 2010, 38, 4547.

(12) (a) Obika, S. Chem. Pharm. Bull. 2004, 52, 1399. (b) Singh, S. K.; Nielsen, P.; Koshkin, A. A.; Wengel, J. Chem. Commun. 1998, 455.

(13) (a) Braasch, D. A.; Jensen, S.; Liu, Y.; Kaur, K.; Arar, K.; White, M. A.; Corey, D. R. Biochemistry 2003, 42, 7967. (b) Elmén, J.; Thonberg, H.; Ljungberg, K.; Frieden, M.; Westergaard, M.; Xu, Y.; Wahren, B.; Liang, Z.; Ørum, H.; Koch, T.; Wahlestedt, C. Nucleic Acids Res. 2005, 33, 439.

(14) Terrazas, M.; Ocampo, S. M.; Perales, J. C.; Marquez, V. E.; Eritja, R. ChemBioChem 2011, in press doi:10.1002/cbic.201000791.

(15) (a) Kim, H. S.; Ravi, R. G.; Marquez, V. E.; Maddileti, S.; Wihlborg, A.-K.; Erlinge, D.; Malmsjö, M.; Boyer, J. L.; Harden, T. K.; Jacobson, K. A. J. Med. Chem. 2002, 45, 208. (b) Ravi, G.; Lee, K.; Ji, X.; Kim, H. S.; Soltysiak, K. A.; Marquez, V. E.; Jacobson, K. A. Bioorg. \& Med. Chem. Lett. 2001, 11, 2295.

(16) For a review, see: Somoza, A. Chem. Soc. Rev. 2008, 37, 2668.

(17) (a) Sproat, B. S. In Oligonucleotide Synthesis: Methods and Applications; Herdewijn, P. Ed.; Humana Press: New Jersey, 2005, Vol. 288, p.17-31. (b) Pitsch, S.; Weiss, P. A.; Jenny, L.; Stutz, A.; Wu, X. Helv. Chim. Acta 2001, 84, 3773. (c) Shiba, Y.; Masuda, H.; Watanabe, N.; Ego, T.; Takagaki, K.; Ishiyama, K.; Ohgi, T.; Yano, J. Nucleic Acids Res. 2007, 35, 3287. (d) Schwartz, M. E.; Breaker, R. R.; Asteriadis, G. T.; deBear, J. S.; Gough, G. R. Bioorg. Med. Chem. Lett. 1992, 2, 1019. (e) Harstel, S. A.; Kitchen, D. E.; Scaringe, S. A.; Marsal, W. S. In Oligonucleotide Synthesis: Methods and Applications; Herdewijn, P. Ed.; Humana Press: New Jersey, 2005, Vol. 288, p.33-49.

(18) Umemoto, T.; Wada, T. Tetrahedron Lett. 2004, 45, 9529.

(19) Ohgi, T.; Masutomi, Y.; Ishiyama, K.; Kitagawa, H.; Shiba, Y.; Yano, J. Org. Lett. 2005, 7, 3477. 


\section{Supporting Information}

\section{A direct, efficient method for the preparation of siRNAs containing ribo-like North bicyclo[3.1.0]hexane pseudosugars}

Montserrat Terrazas, ${ }^{\dagger}$ Anna Aviñó, ${ }^{\dagger}$ Maqbool A. Siddiqui, ${ }^{\dagger}$ Victor E. Marquez, ${ }^{*}{ }^{\dagger}$ and Ramon Eritja*,†

Institute for Research in Biomedicine (IRB Barcelona), Networking Center on Bioengineering, Biomaterials and Nanomedicine (CIBER-BBN), and Institute for Advanced Chemistry of Catalonia (IQAC), Spanish Research Council (CSIC), Cluster Building, Baldiri i Reixac 10, E-08028 Barcelona, Spain, and Laboratory of Chemical Biology, Center for Cancer Research, National Cancer Institute at Frederick, MD. 21702 USA.

\section{Table of contents}

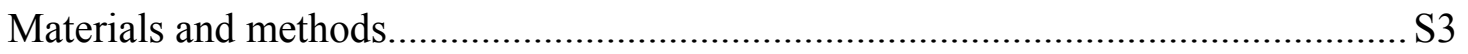

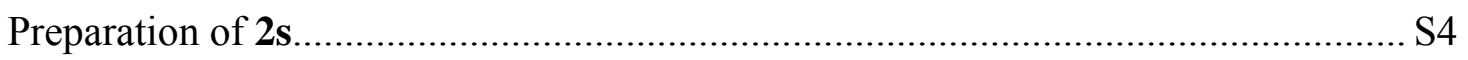

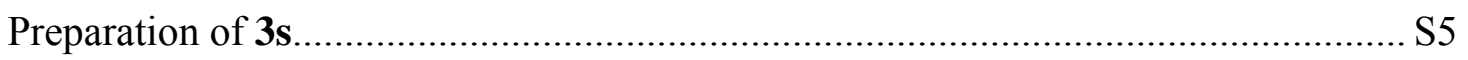

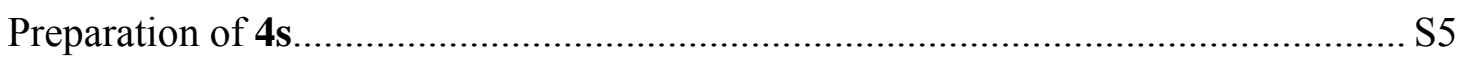

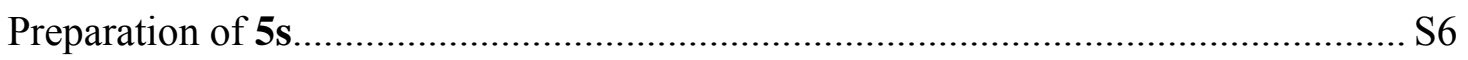

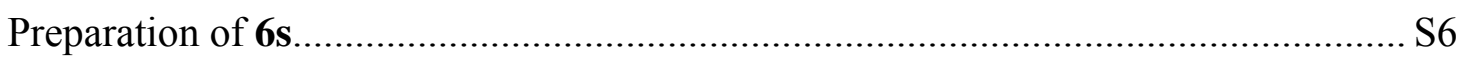

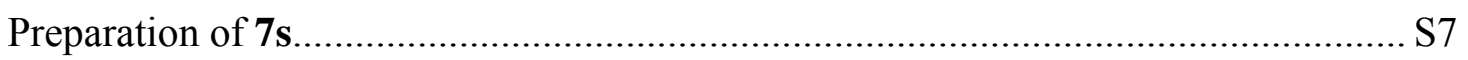

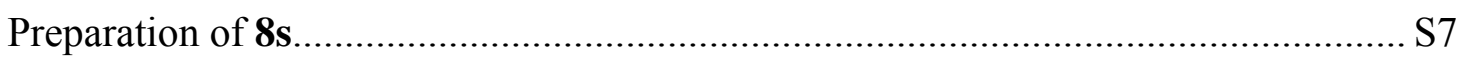

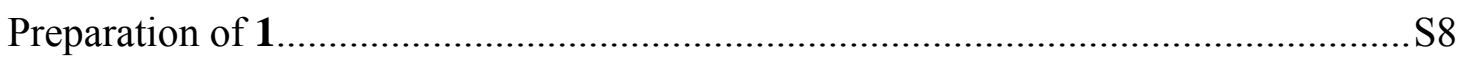

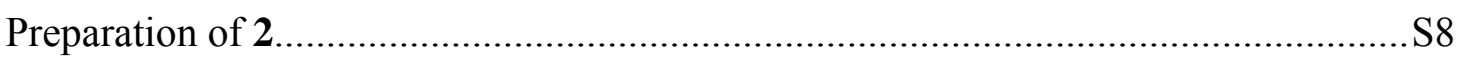

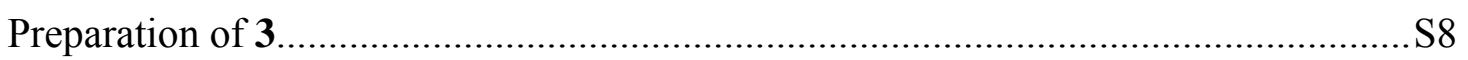

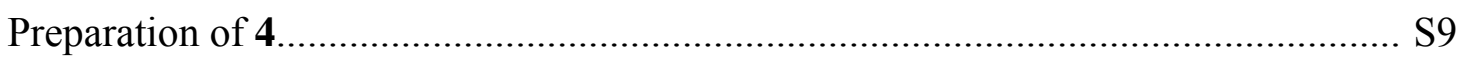

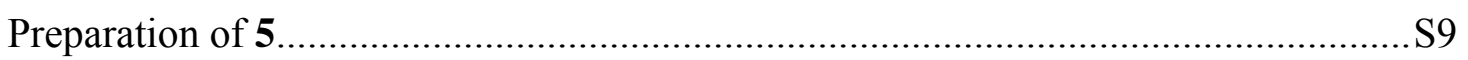

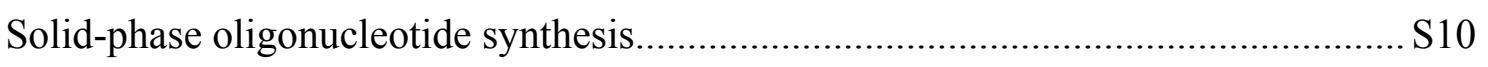

Deprotection and purification of unmodified oligonucleotides

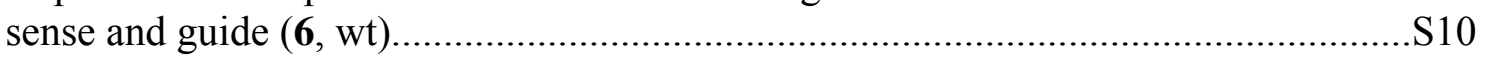

Deprotection and purification of modified oligonucleotides 7 and 8 ......................... S10

General procedure for enzymatic digestion of oligonucleotides............................... S1 1

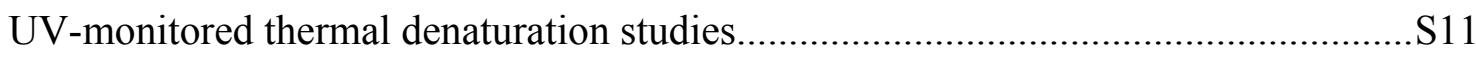

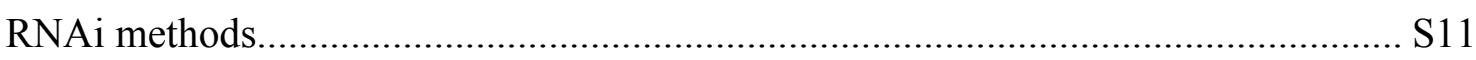

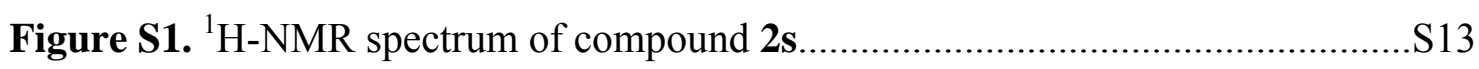

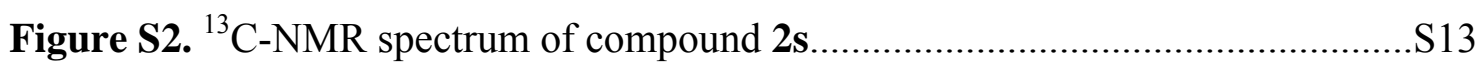




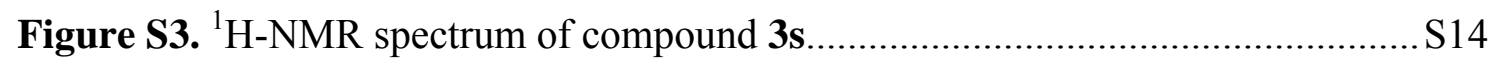

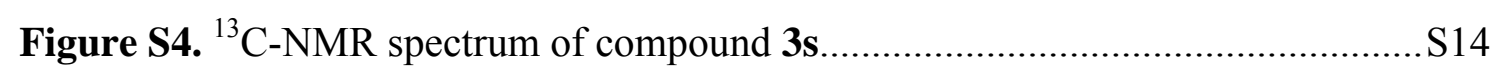

Figure S5. ${ }^{1} \mathrm{H}-\mathrm{NMR}$ spectrum of compound 4s..................................................... S15

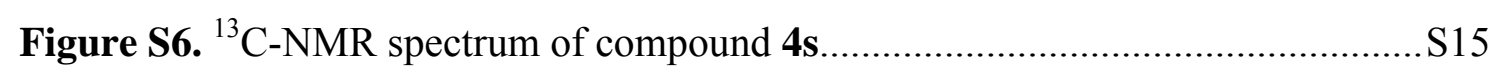

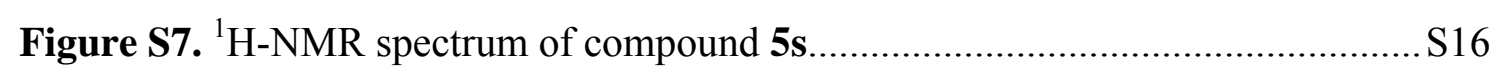

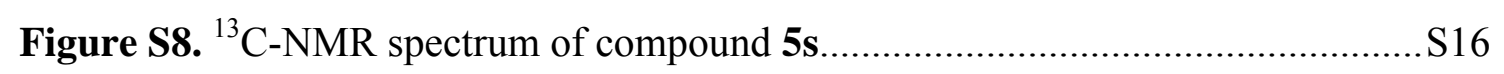

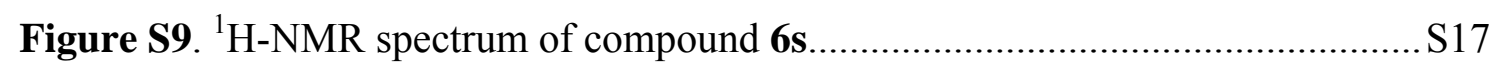

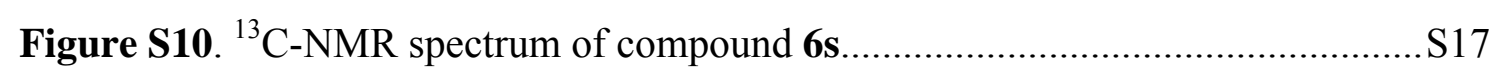

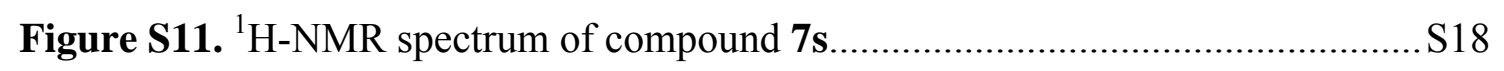

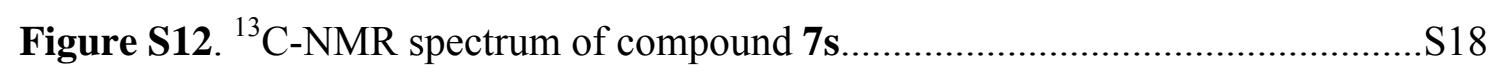

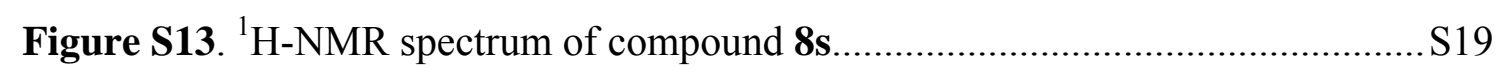

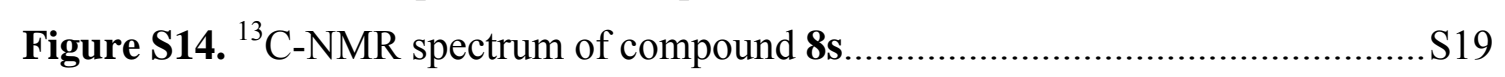

Figure S15. ${ }^{1} \mathrm{H}-\mathrm{NMR}$ spectrum of compound 1................................................ S2

Figure S16. ${ }^{13} \mathrm{C}-\mathrm{NMR}$ spectrum of compound 1.................................................. S2

Figure S17. ${ }^{1} \mathrm{H}-\mathrm{NMR}$ spectrum of compound 2................................................. S2

Figure S18. ${ }^{13} \mathrm{C}-\mathrm{NMR}$ spectrum of compound 2 ............................................... S21

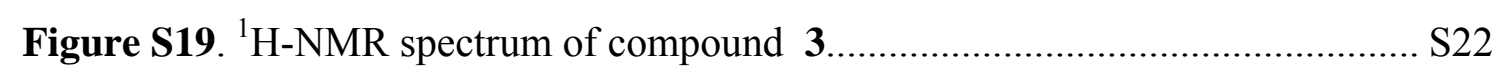

Figure S20. ${ }^{13} \mathrm{C}-\mathrm{NMR}$ spectrum of compound 3............................................... S22

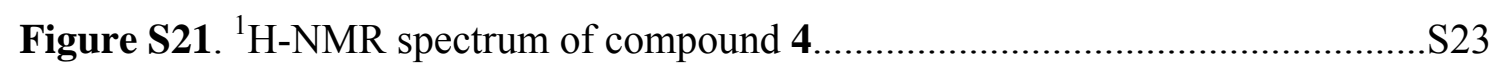

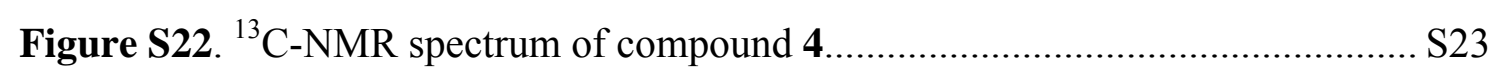

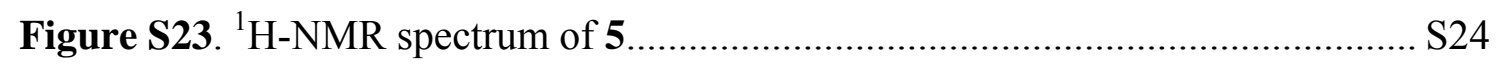

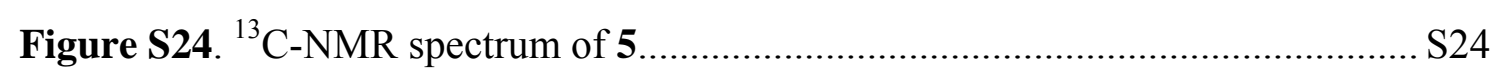

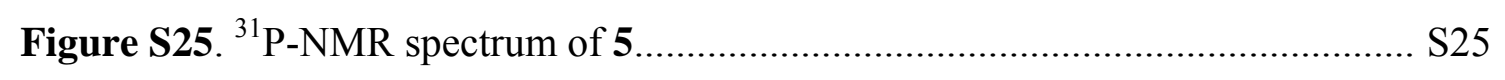

Figure S26. MALDI-TOF mass spectra of synthesized oligonucleotides............... S26

Figure S27. Plot of gene-specific RNAi activity for siRNAs formed by unmodified guide strand $\mathbf{6}$ and modified guide strands $\mathbf{7}$ and $\mathbf{8}$ expressed in SH-SY5Y cells.. 


\section{Materials and Methods}

Common chemicals and solvents in addition to 2-cyanoethyl diisopropylphosphoramidochloridite were purchased from commercial sources and used without further purification. Anhydrous solvents and deuterated solvents $\left(\mathrm{CDCl}_{3}\right.$, $\mathrm{CD}_{3} \mathrm{OD}$ and DMSO- $d_{6}$ ) were obtained from reputable sources and used as received.

Reagents for oligonucleotide synthesis including 2'-O-TBDMS-protected phosphoramidite monomers of $A^{\mathrm{Bz}}, \mathrm{C}^{\mathrm{Ac}}, \mathrm{G}^{\mathrm{dmf}}$ and $\mathrm{U}$, the 5'-deblocking solution (3\% TCA in $\left.\mathrm{CH}_{2} \mathrm{Cl}_{2}\right)$, activator solution $(0.4 \mathrm{M} 1 \mathrm{H}$-tetrazole in $\mathrm{MeCN})$, Cap A solution (acetic anhydride/pyridine/tetrahydrofuran (1:1:8), Cap B solution $\left[\begin{array}{lll}10 \% & N-\end{array}\right.$ methylimidazole in tetrahydrofuran), oxidizing solution $(0.01 \mathrm{M}$ iodine in tetrahydrofuran/pyridine/water (7:2:1) or 70\% tert-butyl hydroperoxide in water, which was diluted to $10 \%$ with acetonitrile (synthesis grade) prior to use] and succinyl polystyrene functionalized with 5'-O-DMT-2'-deoxythymidine were purchased from commercial sources and used as received.

Nuclease P1 and bacterial alkaline phosphatase were commercially available and used without further purification.

All reactions were carried out under argon atmosphere in oven-dried glassware. Thinlayer chromatography was carried out on aluminium-backed Silica-Gel $60 \mathrm{~F}_{254}$ plates. Column chromatography was performed using Silica Gel (60 ̊, 230 x 400 mesh). NMR spectra were measured on Varian Mercury-400 or Varian-300 instruments. Chemical shifts are given in parts per million (ppm); $J$ values are given in hertz $(\mathrm{Hz})$. All spectra were internally referenced to the appropriate residual undeuterated solvent.

RP-HPLC purifications were performed using a Nucleosil $120-10 \mathrm{C}_{18}$ column $(250 \times 4$ $\mathrm{mm})$.

HRMS of compound 5 was performed on a LC/MSD-TOF (Agilent technologies) high resolution mass spectometer by Servei d'Espectrometria de Masses (Universitat de Barcelona). HRMS of compounds 3 and $\mathbf{4}$ was performed by (MALDI, positive ion) on a Shimadzu Axima-CFR curved field reflection TOF mass spectrometer using CHCA as the MALDI matrix.APCI MS analyses were conducted on an Agilent LC-MS using flow-injection analysis. Low resolution MS (FAB) for compounds $\mathbf{2 s}-\mathbf{8 s}$ and $\mathbf{1}$ and $\mathbf{2}$ was performed on a VG $7070 \mathrm{E}$ mas spectrometer and at an accelerating voltage of +8 $\mathrm{kV}$ and ionization was effected by a beam of xenon atoms.

MALDI-TOF spectra were performed using a Perseptive Voyager DETMRP mass spectrometer, equipped with nitrogen laser at $337 \mathrm{~nm}$ using a $3 \mathrm{~ns}$ pulse. The matrix used contained 2,4,6-trihydroxyacetophenone (THAP, $10 \mathrm{mg} / \mathrm{mL}$ in ACN/ water 1:1) and ammonium citrate $(50 \mathrm{mg} / \mathrm{mL}$ in water). 


\section{Synthetic scheme}

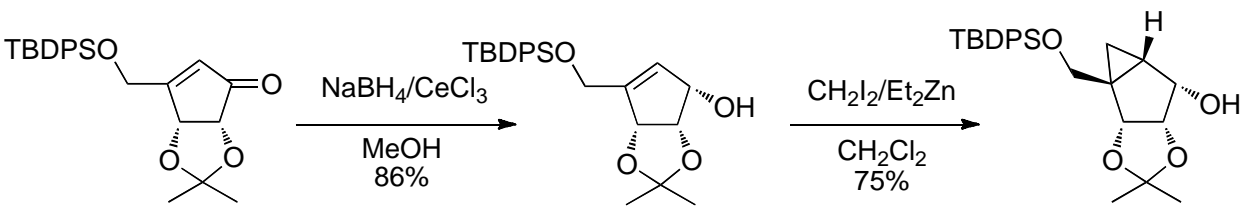<smiles>CC(=O)OCC1CC2(CO1)C1C=CC(=O)NC1C2OC(C)=O</smiles>

$6 s$<smiles>CO/C=C/C(=O)NC=O</smiles>

$$
\begin{aligned}
& \text { 1. } \mathrm{POCl}_{3} \text {, triazole/CH} \mathrm{CH}_{3} \mathrm{CN} \\
& 82 \% \\
& \text { 2. } \mathrm{NH}_{4} \mathrm{OH} / 1,4 \text {-dioxane } \\
& \text { 3. } \mathrm{NH}_{3} / \mathrm{MeOH} \\
& \quad 72 \% \text { (2 steps) }
\end{aligned}
$$

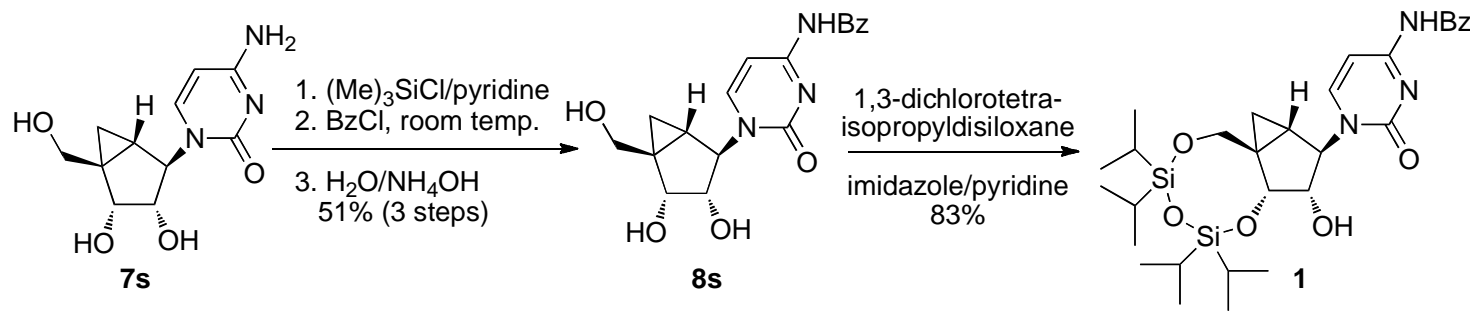

1. $\mathrm{MeSCH}_{2} \mathrm{OCH}_{2} \mathrm{CH}_{2} \mathrm{CN} / \mathrm{THF}$ 2. $\mathrm{CF}_{3} \mathrm{SO}_{3} \mathrm{H}, \mathrm{NIS}\left(-45^{\circ} \mathrm{C}\right)$

3. $\mathrm{Et}_{3} \mathrm{~N}, \mathrm{Na}_{2} \mathrm{~S}_{2} \mathrm{O}_{4}$ $73 \%$<smiles></smiles>

4<smiles></smiles>

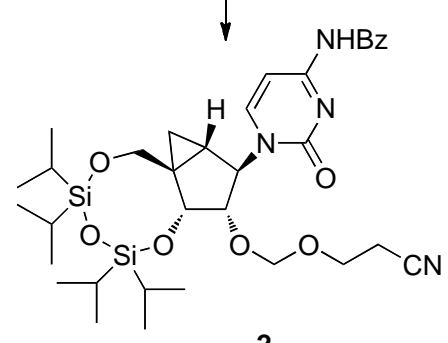

2

\section{Preparation of $2 \mathrm{~s}$}

A solution of cyclopentenone $1 \mathrm{~s}(3.92 \mathrm{~g}, 9.27 \mathrm{mmol})$ in anhydrous methanol $(70 \mathrm{~mL})$ was treated with Cerium(III) chloride heptahydrate $(3.20 \mathrm{~g}, 8.58 \mathrm{mmol})$. The flask was cooled over ice and treated with portions of sodium borohydride $(0.390 \mathrm{~g}, 10.30 \mathrm{mmol})$. After 15 minutes, the $\mathrm{pH}$ was brought to 4 with acetic acid. Immediately after, water (40 $\mathrm{mL})$ was added and the mixture was extracted with ether $(2 \times 100 \mathrm{~mL})$. The combined ether extract was washed with brine $(2 \times 60 \mathrm{~mL})$, dried $\left(\mathrm{MgSO}_{4}\right)$ and concentrated in vacuo. The crude product was purified by flash chromatography over silica gel using 10 $\rightarrow 20 \%$ EtOAc in hexanes to give $3.38 \mathrm{~g}(86.0 \%)$ of $2 \mathrm{~s}$ as an oil: ${ }^{1} \mathrm{H}-\mathrm{NMR}$ (400 MHz, $\left.\mathrm{CDCl}_{3}\right) \delta$ 7.51-7.61 (m, $\left.4 \mathrm{H}\right), 7.27-7.35(\mathrm{~m}, 6 \mathrm{H}), 5.76(\mathrm{~m}, 1 \mathrm{H}), 4.79(\mathrm{~d}, J=5.5 \mathrm{~Hz}, 1$ 
H), $4.67(\mathrm{td}, J=6.3,0.8 \mathrm{~Hz}, 1 \mathrm{H}), 4.48(\mathrm{br} \mathrm{s}, 1 \mathrm{H}), 4.31(\mathrm{dm}, J=15.2 \mathrm{~Hz}, 1 \mathrm{H}), 4.21$ $(\mathrm{dm}, J=15.2 \mathrm{H}, 1 \mathrm{H}), 2.60(\mathrm{br} \mathrm{s}, 1 \mathrm{H}), 1.28(\mathrm{~s}, 3 \mathrm{H}), 1.26(\mathrm{~s}, 3 \mathrm{H}), 1.00(\mathrm{~s}, 9 \mathrm{H}) ;{ }^{13} \mathrm{C}$ NMR $\left(100 \mathrm{MHz}, \mathrm{CDCl}_{3}\right) \delta 145.2,135.5,133.28,129.7,129.6,129.29,127.7,112.4$, 82.8, 77.9, 73.3, 60.8, 27.6, 26.7, 19.2; FABMS $\mathrm{m} / \mathrm{z}$ (relative intensity) $425.2\left(\mathrm{MH}^{+}\right.$, 17), $463.2\left(\mathrm{MK}^{+}, 100\right)$. Anal. Calcd. for $\mathrm{C}_{25} \mathrm{H}_{32} \mathrm{O}_{4} \mathrm{Si}: \mathrm{C}, 70.72 ; \mathrm{H}, 7.60$. Found: $\mathrm{C}$, 70.82; H, 7.60 .

\section{Preparation of $3 s$}

An ice-cold solution of 2s $(10.89 \mathrm{~g}, 25.89 \mathrm{mmol})$ in anhydrous $\mathrm{CH}_{2} \mathrm{Cl}_{2}(150 \mathrm{~mL})$ was stirred and treated with a solution of $\mathrm{Et}_{2} \mathrm{Zn}$ in hexane $(1 \mathrm{M}, 70 \mathrm{~mL}, 70 \mathrm{mmol})$ and $\mathrm{CH}_{2} \mathrm{I}_{2}$ $(6 \mathrm{~mL}, 74.3 \mathrm{mmol})$. After $15 \mathrm{~min}$, the ice bath was removed while stirring continued for $1.5 \mathrm{~h}$. The reaction mixture was quenched with a saturated aqueous solution of $\mathrm{NH}_{4} \mathrm{Cl}$ $(100 \mathrm{~mL})$ and extracted with $\mathrm{CH}_{2} \mathrm{Cl}_{2}(2 \times 100 \mathrm{~mL})$. The combined organic layer was washed with saturated aqueous $\mathrm{NaHCO}_{3}(2 \times 100 \mathrm{~mL})$, water $(2 \times 100 \mathrm{~mL})$, dried $\left(\mathrm{MgSO}_{4}\right)$ and concentrated in vacuo. The crude product was purified by flash chromatography over silica gel using $10 \rightarrow 25 \%$ EtOAc in hexanes to give $8.42 \mathrm{~g}$ (74.8\%) of 3s as a thick oil: ${ }^{1} \mathrm{H}-\mathrm{NMR}\left(400 \mathrm{MHz}, \mathrm{CDCl}_{3}\right) \delta$ 7.60-7.65 (m, $\left.4 \mathrm{H}\right), 7.34-$ $7.42(\mathrm{~m}, 6 \mathrm{H}), 5.00(\mathrm{dd}, J=7.0,1.2 \mathrm{~Hz}, 1 \mathrm{H}), 4.54(\mathrm{dt}, J=7.4,0.8 \mathrm{~Hz}, 1 \mathrm{H}), 4.45$ (br t, $J \approx 6 \mathrm{~Hz}, 1 \mathrm{H}), 4.06(\mathrm{~d}, J=11.3 \mathrm{~Hz}, 1 \mathrm{H}), 3.28(\mathrm{~d}, J=11.3 \mathrm{~Hz}, 1 \mathrm{H}), 2.30(\mathrm{br} \mathrm{s}, 1 \mathrm{H})$, $1.60(\mathrm{~m}, 1 \mathrm{H}), 1.53(\mathrm{~s}, 3 \mathrm{H}), 1.31(\mathrm{~s}, 3 \mathrm{H}), 1.08$ (irregular t, $J \approx 5 \mathrm{~Hz}, 1 \mathrm{H}), 1.00(\mathrm{~s}, 9 \mathrm{H})$, $0.53(\mathrm{~m}, 1 \mathrm{H}) ;{ }^{13} \mathrm{C}$ NMR $\left(100 \mathrm{MHz}, \mathrm{CDCl}_{3}\right) \delta 135.5,133.6,129.7,127.7,112.7,81.1$, 79.7, 71.0, 65.3, 35.5, 32.8, 26.9, 26.1, 24.6, 19.2, 10.3 FABMS $\mathrm{m} / \mathrm{z}$ (relative intensity) 477.2 ( $\left.\mathrm{MK}^{+}, 100\right)$. Anal. Calcd. for $\mathrm{C}_{26} \mathrm{H}_{34} \mathrm{O}_{4} \mathrm{Si}: \mathrm{C}, 71.19 \%$; H, 7.81. Found: C, 71.03; $\mathrm{H}, 8.00$.

\section{Preparation of $4 \mathrm{~s}$}

An ice-cold solution of $3 \mathrm{~s}(8.33 \mathrm{~g}, 18.99 \mathrm{mmol})$ in dry pyridine $(100 \mathrm{~mL})$ was treated with $\mathrm{CH}_{3} \mathrm{SO}_{2} \mathrm{Cl}(3.6 \mathrm{~mL}, 46.5 \mathrm{mmol})$. After $10 \mathrm{~min}$, the reaction mixture was warmed to ambient temperature and stirred for $1.5 \mathrm{~h}$. The solvent was removed in vacuo and the crude product was purified by flash chromatography using $20 \rightarrow 33 \%$ EtOAc in hexanes to give $9.80 \mathrm{~g}(99.8 \%)$ of the intermediate mesylate. This intermediate $(9.80 \mathrm{~g}$, $19.1 \mathrm{mmol})$ was immediately dissolved in anhydrous DMF $(80 \mathrm{~mL})$ and treated with $\mathrm{NaN}_{3}(12.5 \mathrm{~g}, 192.2 \mathrm{mmol})$. The reaction mixture was heated to $100{ }^{\circ} \mathrm{C}$ for $2 \mathrm{~h}$, cooled to ambient temperature, quenched with water $(100 \mathrm{~mL})$ and extracted with $\mathrm{Et}_{2} \mathrm{O}(2 \times$ $150 \mathrm{~mL})$. The combined ether layer was dried $\left(\mathrm{MgSO}_{4}\right)$, concentrated in vacuo and purified by flash chromatography over silica gel using $0 \rightarrow 5 \%$ EtOAc in hexanes to give $7.57 \mathrm{~g}(86.1 \%)$ of $4 \mathrm{~s}$ as a thick oil: ${ }^{1} \mathrm{H}-\mathrm{NMR}\left(400 \mathrm{MHz}, \mathrm{CDCl}_{3}\right) \delta 7.64-7.68(\mathrm{~m}, 4$ H), 7.35-7.45 (m, $6 \mathrm{H}), 5.03(\mathrm{dd}, J=7.0,1.4 \mathrm{~Hz}, 1 \mathrm{H}), 4.50(\mathrm{dd}, J=7.0,1.4 \mathrm{~Hz}, 1 \mathrm{H})$, $4.03(\mathrm{~d}, J=10.9 \mathrm{~Hz}, 1 \mathrm{H}), 3.87(\mathrm{~s}, 1 \mathrm{H}), 3.42(\mathrm{~d}, J=10.9 \mathrm{~Hz}, 1 \mathrm{H}), 1.57$ (ddd, $J=9.3$, 4.7, $1.6 \mathrm{~Hz}, 1 \mathrm{H}), 1.44$ (s, $3 \mathrm{H}), 1.26(\mathrm{~s}, 3 \mathrm{H}), 1.06$ (s, $9 \mathrm{H}), 0.92$ (dd, $J=5.4,4.3 \mathrm{~Hz}, 1$ $\mathrm{H}), 0.75(\mathrm{ddd}, J=7.0,5.4,1.6 \mathrm{~Hz}, 1 \mathrm{H}) ;{ }^{13} \mathrm{C} \mathrm{NMR}\left(100 \mathrm{MHz}, \mathrm{CDCl}_{3}\right) \delta 135.6,133.5$, 133.4, 129.7, 127.7, 111.7, 87.6, 80.9, 65.5, 64.6, 37.9, 29.2, 26.8, 25.9, 24.3, 19.3, 11.9; FABMS m/z (relative intensity) $502.2\left(\mathrm{MK}^{+}, 35\right), 464.2\left(\mathrm{MH}^{+}, 5\right), 406.2\left(\mathrm{MH}^{+}-\right.$ $\left(\mathrm{CH}_{3}\right)_{2} \mathrm{CO}$ ). Anal. Cacld. for $\mathrm{C}_{26} \mathrm{H}_{33} \mathrm{~N}_{3} \mathrm{O}_{3} \mathrm{Si}$ : C, 67.35; H, 7.17; N, 9.06. Found: $\mathrm{C}$, $67.21 ; \mathrm{H}, 7.15 ; \mathrm{N}, 9.04$. 


\section{Preparation of $5 s$}

A stirred, argon-flushed solution of $4 \mathrm{~s}(2.13 \mathrm{~g}, 4.59 \mathrm{mmol})$ in $\mathrm{CH}_{3} \mathrm{OH}: \mathrm{CH}_{2} \mathrm{Cl}_{2}(1: 1,40$ $\mathrm{mL}$ ) was treated with $0.2 \mathrm{~g}$ of Lindlar's catalyst. The inert gas was evacuated and replaced with a hydrogen-filled balloon. After $18 \mathrm{~h}$, the reaction was filtered over short pad of celite and the solvent was evaporated to dryness. The crude product was purified by flash chromatography over silica gel using 5\% EtOAc in hexanes $\rightarrow 100 \%$ EtOAc to give $1.76 \mathrm{~g}(88.0 \%)$ of $5 \mathrm{~s}$ as a thick oil: ${ }^{1} \mathrm{H}-\mathrm{NMR}\left(400 \mathrm{MHz}, \mathrm{CDCl}_{3}\right) \delta 7.65-7.70(\mathrm{~m}, 4$ H), 7.35-7.45 (m, $6 \mathrm{H}), 5.10$ (dd, $J=7.0,1.2 \mathrm{~Hz}, 1 \mathrm{H}), 4.35$ (dd, $J=7.0,1.5 \mathrm{~Hz}, 1 \mathrm{H})$, $4.14(\mathrm{~d}, J=10.9 \mathrm{~Hz}, 1 \mathrm{H}), 3.34(\mathrm{~s}, 1 \mathrm{H}), 3.30$ (d, $J=10.9 \mathrm{~Hz}, 1 \mathrm{H}), 1.47$ (s, $3 \mathrm{H}), 1.42$ (br s, $2 \mathrm{H}), 1.26(\mathrm{~m}, 4 \mathrm{H}), 1.06(\mathrm{~s}, 9 \mathrm{H}), 0.91$ (irregular t, $J \approx 5 \mathrm{~Hz}, 1 \mathrm{H}), 0.60$ (ddd, $J=$ 8.9, 5.4, $1.6 \mathrm{~Hz}, 1 \mathrm{H}) ;{ }^{13} \mathrm{C} \mathrm{NMR}\left(100 \mathrm{MHz}, \mathrm{CDCl}_{3}\right) \delta 135.6,133.6,129.7,127.7,111.0$, $91.2,80.8,65.5,56.7,37.3$ 33.4, 26.9, 26.0, 24.3, 19.3, 12.6; FABMS $\mathrm{m} / \mathrm{z}$ (relative intensity) $467.72\left(\mathrm{MK}^{+}, 10\right), 438.3\left(\mathrm{MH}^{+}, 20\right)$. Anal. Calcd. for $\mathrm{C}_{26} \mathrm{H}_{35} \mathrm{NO}_{3} \mathrm{Si}: \mathrm{C}, 71.35$; H, 8.06; N, 3.20. Found: C, 71.15; H, 8.10; N, 3.17.

\section{Preparation of $6 \mathbf{s}$}

A solution of dried AgNCO (4.3 g, 28.6mmol) in anhydrous benzene $(60 \mathrm{~mL})$ was maintained under argon and treated with freshly prepared 3-methoxyacryloyl chloride $(1.80 \mathrm{~g}, 14.93 \mathrm{mmol})$, which was added drop-wise at ambient temperature. The mixture was then heated to reflux for $1 \mathrm{~h}$ and again allowed to reach ambient temperature. After the mixture settled, the supernatant was added via syringe to a stirred, ice-cold solution of $5 \mathrm{~s}(3.0 \mathrm{~g}, 6.85 \mathrm{mmol})$ in anhydrous $\mathrm{CH}_{2} \mathrm{Cl}_{2}(50 \mathrm{~mL})$ that was maintained under an argon atmosphere. The solution was allowed to warm up to ambient temperature and was stirred for $1.5 \mathrm{~h}$. The solvent was then evaporated and the residue was purified by flash chromatography over silica gel using $20 \% \rightarrow 50 \%$ EtOAc in hexanes to give 3.70 $\mathrm{g}(95.6 \%)$ of the 3-methoxyacryloyl ureido intermediate. This intermediate was dissolved in ethanol $(100 \mathrm{~mL})$ and treated with $2 \mathrm{~N}$ aqueous $\mathrm{HCl}(10 \mathrm{~mL})$. The solution was then heated to reflux overnight and after cooling to ambient temperature the solvent was removed in vacuo. The residue was triturated with EtOAc $(10 \mathrm{~mL})$ and the solid obtained was filtered and washed with hexanes $(5 \mathrm{~mL})$. After drying under vacuum, $1.60 \mathrm{~g} \mathrm{(96.4 \% )}$ of the free, unprotected uracil nucleoside was obtained: ${ }^{1} \mathrm{H}-\mathrm{NMR}$ (400 MHz, DMSO-d $\left.d_{6}\right) \delta 7.86(\mathrm{~d}, J=8.0 \mathrm{~Hz}, 1 \mathrm{H}), 5.50(\mathrm{~d}, J=8.0 \mathrm{~Hz}, 1 \mathrm{H}), 4.98(\mathrm{~d}, J=4.3$ $\mathrm{Hz}, 1 \mathrm{H}, \mathrm{D}_{2} \mathrm{O}$ exchanged), $4.90\left(\mathrm{t}, J=5.0 \mathrm{~Hz}, 1 \mathrm{H}, \mathrm{D}_{2} \mathrm{O}\right.$ exchanged), 4.54 (s, $\left.1 \mathrm{H}\right), 4.29$ $4.38\left(\mathrm{~m}, 2 \mathrm{H}\right.$; d at 4.30, $J=6.6,1.6 \mathrm{~Hz}$ after $\left.\mathrm{D}_{2} \mathrm{O}\right), 3.95(\mathrm{dd}, J=11.3,5.0 \mathrm{~Hz}, 1 \mathrm{H}$; d at 3.92, d after $\left.\mathrm{D}_{2} \mathrm{O}\right), 3.56$ (br t, $\left.1 \mathrm{H}\right), 3.02\left(\mathrm{dd}, J=11.3,4.8 \mathrm{~Hz}, 1 \mathrm{H} ; \mathrm{d} 3.00\right.$ after $\mathrm{D}_{2} \mathrm{O}$ ), $1.09-1.15\left(\mathrm{~m}, 2 \mathrm{H}\right.$; irregular dd at 1.14 and irregular $\mathrm{t}$ at 1.10 after $\left.\mathrm{D}_{2} \mathrm{O}\right), 0.49(\mathrm{~m}, 1 \mathrm{H}$; ddd, $J=8.5,4.3,1.6 \mathrm{~Hz}$ after $\left.\mathrm{D}_{2} \mathrm{O}\right)$; FABMS $\mathrm{m} / \mathrm{z}$ (relative intensity) $255.1\left(\mathrm{MH}^{+}, 100\right)$, $113\left(\mathrm{bH}_{2}^{+}, 35\right)$. Because this material had a trace impurity, the combined total from this reaction and that of a second reaction $(2.43 \mathrm{~g}, 9.55 \mathrm{mmol})$ was suspended in anhydrous pyridine $(60 \mathrm{~mL})$ and treated with $\mathrm{Ac}_{2} \mathrm{O}(6.0 \mathrm{~mL}, 63.5 \mathrm{mmol})$. After stirring for $1.5 \mathrm{~h}$, the solvent was removed in vacuo, co-evaporated thrice with toluene $(3 \times 10 \mathrm{~mL})$ and the crude residue was purified by flash chromatography over silica gel using $50 \%$ EtOAc in hexanes $\rightarrow 100 \%$ EtOAc to give $3.18 \mathrm{~g}(88.9 \%)$ of $6 \mathrm{~s}$ as a pure oil: ${ }^{1} \mathrm{H}-\mathrm{NMR}$ $\left(400 \mathrm{MHz}, \mathrm{CDCl}_{3}\right) \delta 8.98($ br s, $1 \mathrm{H}), 7.35(\mathrm{~d}, J=8.2 \mathrm{~Hz}, 1 \mathrm{H}), 5.70(\mathrm{dd}, J=8.2,2.3$ $\mathrm{Hz}, 1 \mathrm{H}), 5.66(\mathrm{dd}, J=7.4,1.6 \mathrm{~Hz}, 1 \mathrm{H}), 5.16(\mathrm{dt}, J=7.4,1.6 \mathrm{~Hz}, 1 \mathrm{H}), 4.60(\mathrm{~s}, 1 \mathrm{H})$, $4.40(\mathrm{~d}, J=12.1 \mathrm{~Hz}, 1 \mathrm{H}), 3.94(\mathrm{~d}, J=12.1 \mathrm{~Hz}, 1 \mathrm{H}), 2.07(\mathrm{~s}, 3 \mathrm{H}), 2.02(\mathrm{~s}, 6 \mathrm{H}), 1.46$ (dd, $J=8.6,4.3 \mathrm{~Hz}, 1 \mathrm{H}$ ), 1.23 (dd, $J=6.2,4.3 \mathrm{~Hz}, 1 \mathrm{H}$ ), 0.97 (ddd, $J=8.6,6.2,1.6$ $\mathrm{Hz}, 1 \mathrm{H}) ;{ }^{13} \mathrm{C}$ NMR $\left(100 \mathrm{MHz}, \mathrm{CDCl}_{3}\right) \delta 170.6,170.0,169.0,162.8,150.2,141.6$, $102.8,76.1,72.8,65.2,64.5,33.2,23.8,20.7,20.5,20.4,12.6$; FABMS $\mathrm{m} / \mathrm{z}$ (relative 
intensity) $381.1\left(\mathrm{MH}^{+}, 100\right), 113\left(\mathrm{bH}_{2}{ }^{+}, 10\right)$. Anal. Calcd. for $\mathrm{C}_{17} \mathrm{H}_{20} \mathrm{~N}_{2} \mathrm{O}_{8}: \mathrm{C}, 53.68 ; \mathrm{H}$, 5.30; N, 7.37. Found: C, 53.56; H, 5.25; N, 7.29.

\section{Preparation of 7s}

A stirred solution of $6 \mathrm{~s}(3.17 \mathrm{~g}, 8.33 \mathrm{mmol}), \mathrm{Et}_{3} \mathrm{~N}(12.10 \mathrm{~mL}, 86.80 \mathrm{mmol})$ and triazole $(5.90 \mathrm{~g}, 85.40 \mathrm{mmol})$ in acetonitrile $(150 \mathrm{~mL})$ was cooled over an ice bath. $\mathrm{POCl}_{3}(1.60$ $\mathrm{mL}, 17.40 \mathrm{mmol}$ ) was added dropwise and after $15 \mathrm{~min}$ the ice bath was removed while stirring continued overnight. The solvent was evaporated and the residue was dissolved in EtOAc $(300 \mathrm{~mL})$, washed with water $(2 \times 100 \mathrm{~mL})$ and dried $\left(\mathrm{MgSO}_{4}\right)$. After removing the solvent in vacuo, the crude residue was purified by flash chromatography over silica gel using 50\% EtOAc in hexanes $\rightarrow 100 \%$ EtOAc to give $2.94 \mathrm{~g}(81.8 \%)$ of the triazole intermediate as a foam. This material was dissolved in 1,4-dioxane $(60 \mathrm{~mL})$ and treated with concentrated $\mathrm{NH}_{4} \mathrm{OH}(15 \mathrm{~mL})$. After stirring at ambient temperature overnight, the solvent was removed in vacuo and the residue was co-evaporated with ethanol $(2 \times 10 \mathrm{~mL})$ and toluene $(2 \times 25 \mathrm{~mL})$. The residual material was dissolved in a small amount of methanol and treated in a sealed flask with saturated methanolic ammonia. The mixture was stirred at ambient temperature overnight and after all volatiles were removed the solid obtained was purified by flash chromatography over silica gel using $25 \% \rightarrow 50 \% \mathrm{MeOH}$ in $\mathrm{CH}_{2} \mathrm{Cl}_{2}$ to give $1.23 \mathrm{~g}(71.5 \%)$ of $7 \mathrm{~s}$ as a solid, mp 242-243 ${ }^{\circ} \mathrm{C} ;[\alpha]^{20}{ }_{\mathrm{D}}=+13.1$ (c $0.50 \mathrm{DMF}$ ). The ${ }^{1} \mathrm{H}-\mathrm{NMR}$ spectrum in Figure $\mathrm{S} 11$ is in DMSO- $d_{6}$; a better resolution was obtained after $\mathrm{D}_{2} \mathrm{O}$ exchange: ${ }^{1} \mathrm{H}-\mathrm{NMR}(400 \mathrm{MHz}$, DMSO- $\left.d_{6}+\mathrm{D}_{2} \mathrm{O}\right) \delta 7.80(\mathrm{~d}, J=7.4 \mathrm{~Hz}, 1 \mathrm{H}), 5.67(\mathrm{~d}, J=7.4 \mathrm{~Hz}, 1 \mathrm{H}), 4.57(\mathrm{~s}, 1 \mathrm{H})$, $4.28(\mathrm{~d}, J=5.8 \mathrm{~Hz}, 1 \mathrm{H}), 3.93(\mathrm{~d}, J=11.3 \mathrm{~Hz}, 1 \mathrm{H}), 3.46(\mathrm{~d}, J=6.6 \mathrm{~Hz}, 1 \mathrm{H}), 3.02(\mathrm{~d}, J$ $=11.3 \mathrm{~Hz}, 1 \mathrm{H}), 1.08-1.11(\mathrm{~m}, 2 \mathrm{H}), 0.48(\mathrm{br} \mathrm{dd}, J=10.1,6.2 \mathrm{~Hz}, 1 \mathrm{H}) ;{ }^{13} \mathrm{C} \mathrm{NMR}$ $\left(100 \mathrm{MHz}, \mathrm{DMSO}-d_{6}+\mathrm{D}_{2} \mathrm{O}\right) \delta 165.7,155.9,142.8,93.8,76.6,70.6,63.3,62.5,37.2$, 22.8, 11.1; FABMS m/z (relative intensity) $254.1\left(\mathrm{MH}^{+}, 100\right), 112.1\left(\mathrm{bH}_{2}{ }^{+}, 40\right)$. Anal. Calcd. for $\mathrm{C}_{11} \mathrm{H}_{15} \mathrm{~N}_{3} \mathrm{O}_{4} \bullet 0.25 \mathrm{H}_{2} \mathrm{O}: \mathrm{C}, 51.26 ; \mathrm{H}, 6.06 ; \mathrm{N}, 16.30$. Found: C, 51.50; H, 6.10; $\mathrm{N}, 16.20$.

\section{Preparation of 8s}

A stirred suspension of nucleoside $7 \mathrm{~s}(0.96 \mathrm{~g}, 3.79 \mathrm{mmol})$ in anhydrous pyridine (60 $\mathrm{mL}$ ) was treated with $\mathrm{Me}_{3} \mathrm{SiCl}(4.80 \mathrm{~mL}, 37.86 \mathrm{mmol})$. After $15 \mathrm{~min}$, benzoyl chloride $(2.40 \mathrm{~mL}, 20.65 \mathrm{mmol})$ was added and kept at ambient temperature for $20 \mathrm{~h}$. After cooling over an ice-bath, the reaction was quenched with water $(4 \mathrm{~mL})$ and concentrated $\mathrm{NH}_{4} \mathrm{OH}(10 \mathrm{~mL})$. After $20 \mathrm{~min}$, the ice bath was removed and stirring continued for 20 min. After removing all volatiles in vacuo the residue was dissolved in water $(150 \mathrm{~mL})$ and washed with $\mathrm{Et}_{2} \mathrm{O}(2 \times 75 \mathrm{~mL})$. The aqueous layer was concentrated and lyophilized and then purified twice by flash chromatography over silica gel using 2 $\rightarrow 10 \% \mathrm{MeOH}$ in $\mathrm{CH}_{2} \mathrm{Cl}_{2}$ to give $0.686 \mathrm{~g}(50.8 \%)$ of $8 \mathrm{~s}$ as a foam. The ${ }^{1} \mathrm{H}-\mathrm{NMR}$ spectrum in Figure $\mathrm{S} 12$ is in DMSO- $d_{6}$; a better resolution was obtained after $\mathrm{D}_{2} \mathrm{O}$ exchange: ${ }^{1} \mathrm{H}-\mathrm{NMR}\left(400 \mathrm{MHz}, \mathrm{DMSO}-\mathrm{d}_{6}+\mathrm{D}_{2} \mathrm{O}\right) \delta 8.37(\mathrm{~d}, J=7.0 \mathrm{~Hz}, 1 \mathrm{H}), 7.92(\mathrm{~d}, J$ $=7.8 \mathrm{~Hz}, 2 \mathrm{H}), 7.44-7.59(\mathrm{~m}, 3 \mathrm{H}), 7.26(\mathrm{~d}, J=7.4 \mathrm{~Hz}, 1 \mathrm{H}), 4.69(\mathrm{~s}, 1 \mathrm{H}), 4.35(\mathrm{dd}, J$ $=6.6,1.2 \mathrm{~Hz}, 1 \mathrm{H}), 3.97(\mathrm{~d}, J=11.3 \mathrm{~Hz}, 1 \mathrm{H}), 3.60(\mathrm{~m}, 1 \mathrm{H}), 3.05(\mathrm{~d}, J=11.3 \mathrm{~Hz}, 1$ $\mathrm{H}$ ), 1.23 - 1.26 (irregular dd, $1 \mathrm{H}$ ), 1.20 (irregular t, $1 \mathrm{H}$ ), 0.55 (ddd, $J=8.1,4.7,1.6$ $\mathrm{Hz}, 1 \mathrm{H}) ;{ }^{13} \mathrm{C}$ NMR $\left(100 \mathrm{MHz}\right.$, DMSO- $\left.d_{6}+\mathrm{D}_{2} \mathrm{O}\right) \delta 167.7,162.8,155.4,147.0,133.6$, 133.1, 128.8, 96.3, 76.1, 70.4, 64.3, 62.4, 55.3, 37.3, 22.7, 11.3; FABMS $\mathrm{m} / \mathrm{z}$ (relative intensity) $358.1\left(\mathrm{MH}^{+}, 100\right), 216.1\left(\mathrm{bH}_{2}^{+}, 65\right)$. Anal. Calcd for $\mathrm{C}_{18} \mathrm{H}_{19} \mathrm{~N}_{3} \mathrm{O}_{5} \bullet 0.40 \mathrm{CH}_{2} \mathrm{Cl}_{2}$ : C, 56.47; H, 5.09; N, 10.73. Found: C, 56.35; H, 5.24; N, 10.95 . 


\section{Preparation of 1}

A suspension of nucleoside $8 \mathrm{~s}(0.55 \mathrm{~g}, 1.53 \mathrm{mmol})$ in anhydrous pyridine $(20 \mathrm{~mL})$ containing imidazole $(0.14 \mathrm{~g}, 2.05 \mathrm{mmol})$ was treated with 1,3-dichlorotetraisopropyl disiloxane (TIPS-Cl $, 0.90 \mathrm{~mL}, 2.85 \mathrm{mmol}$ ). The mixture was stirred at ambient temperature for $1.5 \mathrm{~h}$ and then quenched with water $(50 \mathrm{~mL})$. Following the extraction with EtOAc $(2 \times 75 \mathrm{~mL})$, the combined organic layer was dried $\left(\mathrm{MgSO}_{4}\right)$, concentrated in vacuo and purified by flash chromatography over silica gel using $50 \rightarrow 80 \%$ EtOAc in hexanes to give $0.765 \mathrm{~g}(82.80 \%)$ of $\mathbf{1}$ as foam: ${ }^{1} \mathrm{H}-\mathrm{NMR}\left(400 \mathrm{MHz}, \mathrm{CDCl}_{3}\right) \delta 8.80$ (br s, $1 \mathrm{H}), 7.96(\mathrm{~d}, J=7.4 \mathrm{~Hz}, 1 \mathrm{H}), 7.85(\mathrm{v}$ br d, $J=5.0 \mathrm{~Hz}, 2 \mathrm{H}), 7.43-7.57(\mathrm{~m}, 3 \mathrm{H})$, $4.85(\mathrm{~s}, 1 \mathrm{H}), 4.83(\mathrm{dd}, J=6.6,1.2 \mathrm{~Hz}, 1 \mathrm{H}), 4.05(\mathrm{~d}, J=12.5 \mathrm{~Hz}, 1 \mathrm{H}), 3.88(\mathrm{~d}, J=6.6$ $\mathrm{Hz}, 1 \mathrm{H}), 3.59(\mathrm{~d}, J=12.5 \mathrm{~Hz}, 1 \mathrm{H}), 2.78(\mathrm{~s}, 1 \mathrm{H}), 1.50(\mathrm{dd}, J=3.8,5.6 \mathrm{~Hz}, 1 \mathrm{H}), 1.30$ (ddd, $J=1.2,3.6,8.9 \mathrm{~Hz}, 1 \mathrm{H}), 0.90-1.08(\mathrm{~m}, 28 \mathrm{H}), 0.55$ (ddd, $J=1.6,5.6,8.7 \mathrm{~Hz}, 1$ $\mathrm{H}) ;{ }^{13} \mathrm{C}$ NMR $\left(100 \mathrm{MHz}, \mathrm{CDCl}_{3}\right) \delta 160.8,145.1,132.1,128.0,126.6,95.7,70.6,63.5$, $62.9,35.2,24.3,24.1,16.4,16.3,16.1,16.0,12.4,12.0,12.1,11.8,8.9 ;$ FABMS m/z (relative intensity) $600.3\left(\mathrm{MH}^{+}, 100\right), 216.1 \quad\left(\mathrm{bH}_{2}^{+}, 68\right)$. Anal. Calcd. for $\mathrm{C}_{30} \mathrm{H}_{45} \mathrm{~N}_{3} \mathrm{O}_{6} \mathrm{Si}_{2}: \mathrm{C}, 60.07 ; \mathrm{H}, 5.56 ; \mathrm{N}, 7.00$. Found: C, 60.01; H, 5.69; N, 6.76.

\section{Preparation of 2}

A stirred solution of $1(0.360 \mathrm{~g}, 0.60 \mathrm{mmol})$ in anhydrous THF $(25 \mathrm{~mL})$ over molecular sieves $(4 \mathrm{~A}, 0.60 \mathrm{~g})$ was treated with a freshly prepared solution of 2-cyanoethyl methylthiomethyl ether $(0.48 \mathrm{~g}, 3.65 \mathrm{mmol})$. The solution was cooled to $-45^{\circ} \mathrm{C}$ and treated with trifluoromethane sulfonic acid $(0.30 \mathrm{~mL}, 3.37 \mathrm{mmol})$ and $\mathrm{N}$ iodosuccinimide (NIS, $0.70 \mathrm{~g}, 3.11 \mathrm{mmol}$ ). After $30 \mathrm{~min}$, the cooling bath removed and kept for $1.5 \mathrm{~h}$ before cooling again to $-45^{\circ} \mathrm{C}$ to quench the reaction with $\mathrm{Et}_{3} \mathrm{~N}(0.80$ $\mathrm{mL})$. The precipitate was removed by filtration and the filtrate was diluted with EtOAc $(200 \mathrm{~mL})$ and successively washed with $1 \mathrm{M}$ aqueous $\mathrm{Na}_{2} \mathrm{~S}_{2} \mathrm{O}_{4}(1 \times 60 \mathrm{~mL})$, saturated aqueous $\mathrm{NaHCO}_{3}(1 \times 60 \mathrm{~mL})$ and brine $(1 \times 60 \mathrm{~mL})$. After removing the solvent the residue was purified by flash chromatography over silica gel using $2 \rightarrow 5 \% \mathrm{MeOH}$ in $\mathrm{CH}_{2} \mathrm{Cl}_{2}$ to give $0.30 \mathrm{~g}(73.3 \%)$ of 2 as a foam: ${ }^{1} \mathrm{H}-\mathrm{NMR}\left(400 \mathrm{MHz}, \mathrm{CDCl}_{3}\right) \delta 8.17(\mathrm{~d}, J$ $=7.0 \mathrm{~Hz}, 1 \mathrm{H}), 7.84($ overlapped br d, $2 \mathrm{H}), 7.43-7.57(\mathrm{~m}, 4 \mathrm{H}), 4.88(\mathrm{~s}, 1 \mathrm{H}), 4.79(\mathrm{~m}$, $2 \mathrm{H}), 4.70(\mathrm{~d}, J=6.2 \mathrm{~Hz}, 1 \mathrm{H}), 4.32(\mathrm{~d}, J=12.5 \mathrm{~Hz}, 1 \mathrm{H}), 4.00(\mathrm{~m}, 1 \mathrm{H}), 3.81(\mathrm{~d}, J=$ $6.2 \mathrm{~Hz}, 1 \mathrm{H}), 3.64(\mathrm{~m}, 1 \mathrm{H}), 3.29(\mathrm{~d}, J=12.5 \mathrm{~Hz}, 1 \mathrm{H}), 2.65(\mathrm{~m}, 2 \mathrm{H}), 1.64(\mathrm{dd}, J=5.4$, $3.5 \mathrm{~Hz}, 1 \mathrm{H}), 1.25$ (v br dd, $1 \mathrm{H}), 1.03(\mathrm{~m}, 28 \mathrm{H}), 0.50$ (v br ddd, $1 \mathrm{H}) ;{ }^{13} \mathrm{C}$ NMR $(100$ $\left.\mathrm{MHz}, \mathrm{CDCl}_{3}\right) \delta 160.8,144.3,132.2,132.0,128.0,126.5,117.21,95.8,93.6,69.6,61.8$, 61.5, 61.4, 33.7, 25.5, 21.8, 17.7, 16.4, 16.3, 16.1, 16.0, 15.9, 12.4, 12.1, 12.0, 11.9, 7.7; FABMS $\mathrm{m} / \mathrm{z}$ (relative intensity) $683.3\left(\mathrm{MH}^{+}, 100\right), 216.0\left(\mathrm{bH}_{2}{ }^{+}, 42\right)$. Anal. Calcd. for $\mathrm{C}_{33} \mathrm{H}_{50} \mathrm{~N}_{4} \mathrm{O}_{7} \mathrm{Si}_{2} \bullet 0.50 \mathrm{H}_{2} \mathrm{O}$ : C, 59.01; H, 7.42; N, 8.10. Found: C, 59.09; H, 7.42; N, 7.85.

\section{Preparation of 3}

A stirred solution of $2(0.205 \mathrm{~g}, 0.30 \mathrm{mmol})$ in $\mathrm{MeOH}(25 \mathrm{~mL})$ was treated with $\mathrm{NH}_{4} \mathrm{~F} \cdot 0.5 \mathrm{H}_{2} \mathrm{O}(0.412 \mathrm{~g}, 8.94 \mathrm{mmol})$ and heated to $55{ }^{\circ} \mathrm{C}$ for $2 \mathrm{~h}$. After cooling to ambient temperature, the solvent was removed in vacuo and the residue was purified by flash column chromatography over silica gel using $5 \rightarrow 10 \% \mathrm{MeOH}$ in $\mathrm{CH}_{2} \mathrm{Cl}_{2}$ to give $0.119 \mathrm{~g}(90.10 \%)$ of 3 as a foam: ${ }^{1} \mathrm{H}-\mathrm{NMR}\left(400 \mathrm{MHz}, \mathrm{DMSO}-d_{6}\right) \delta 11.30(\mathrm{~s}, 1 \mathrm{H}), 8.56$ $(\mathrm{d}, J=7.4 \mathrm{~Hz}, 1 \mathrm{H}), 8.07(\mathrm{~d}, J=7.4 \mathrm{~Hz}, 2 \mathrm{H}), 7.69(\mathrm{t}, J=7.4 \mathrm{~Hz}, 1 \mathrm{H}), 7.57(\mathrm{t}, J=7.8$ $\mathrm{Hz}, 2 \mathrm{H}), 7.40(\mathrm{br} \mathrm{d}, J=6.6 \mathrm{~Hz}), 5.13(\mathrm{t}, J=5.0 \mathrm{~Hz}, 1 \mathrm{H}), 4.93(\mathrm{~d}, J=6.6 \mathrm{~Hz}, 1 \mathrm{H})$, $4.80(\mathrm{~s}, 1 \mathrm{H}), 4.78(\mathrm{~d}, J=7.0 \mathrm{~Hz}, 1 \mathrm{H}), 4.66(\mathrm{~d}, J=8.0 \mathrm{~Hz}, 1 \mathrm{H}), 4.57$ (irregular t, $1 \mathrm{H}$ ), $4.13(\mathrm{dd}, J=11.3,5.0 \mathrm{~Hz}, 1 \mathrm{H}), 3.79(\mathrm{t}, J=6.2 \mathrm{~Hz}, 2 \mathrm{H}), 3.74(\mathrm{~d}, J=6.6 \mathrm{~Hz}, 1 \mathrm{H}), 3.20$ (dd, $J=11.3,4.6 \mathrm{~Hz}, 1 \mathrm{H}), 2.84(\mathrm{t}, J=6.2 \mathrm{~Hz}, 2 \mathrm{H}), 1.43(\mathrm{br} \mathrm{dd}, J \approx 8,3 \mathrm{~Hz}, 1 \mathrm{H}), 1.29$ (br t, $J=4.3 \mathrm{~Hz}, 1 \mathrm{H}), 0.70$ (v br ddd, $1 \mathrm{H}) ;{ }^{13} \mathrm{C} \mathrm{NMR}\left(100 \mathrm{MHz}, \mathrm{CH}_{3} \mathrm{OH}-d_{4}\right) \delta 162.8$, 
146.3, 132.6, 129.0, 128.3, 128.1, 127.7, 118.2, 94.00, 79.5, 70.8, 63.4, 62.5 62.2, 36.7, 21.6, 17.7, 10.2; FIA-APCl/MS m/z (relative intensity) $441.2\left(\mathrm{MH}^{+}, 100\right)$. HRMS (MALDI, positive ion) calcd for $\mathrm{C}_{22} \mathrm{H}_{24} \mathrm{~N}_{4} \mathrm{O}_{6}: 441.1774\left(\mathrm{MH}^{+}\right)$, found: 441.1770 .

\section{Preparation of 4}

A solution of $3(0.240 \mathrm{~g}, 0.54 \mathrm{mmol})$ in pyridine was thrice evaporated $(3 \times 5 \mathrm{~mL})$ and finally dissolved in anhydrous pyridine $(15 \mathrm{~mL})$. After cooling over an ice bath, the solution was treated with 4,4'-dimethoxytrityl chloride (DMT-Cl, 0.85g; $2.51 \mathrm{mmol}$ ) and stirred for $30 \mathrm{~min}$. The ice bath was then removed and after $2 \mathrm{~h}$, EtOAc $(200 \mathrm{~mL})$ was added and the organic layer was washed with water $(2 \times 100 \mathrm{~mL})$, dried $\left(\mathrm{MgSO}_{4}\right)$ and concentrated in vacuo. The crude product was purified by flash chromatography over silica gel using $0.4 \% \mathrm{Et}_{3} \mathrm{~N}$ in EtOAc to give a semisolid product that was triturated with hexanes $(10 \mathrm{~mL})$, filtered-off and dried in vacuo at $40{ }^{\circ} \mathrm{C}$ for $12 \mathrm{~h}$ to give $0.266 \mathrm{~g}$ $(65.8 \%)$ of 4 as a foam: ${ }^{1} \mathrm{H}-\mathrm{NMR}\left(400 \mathrm{MHz}, \mathrm{CH}_{3} \mathrm{OH}-\mathrm{d}_{4}\right) \delta 8.75(\mathrm{~d}, J=7.4 \mathrm{~Hz}, 1 \mathrm{H})$, $7.95(\mathrm{~m}, 2 \mathrm{H}), 7.20-7.63(\mathrm{~m}, 13 \mathrm{H}), 6.88(\mathrm{~m}, 4 \mathrm{H}), 4.93-5.00(\mathrm{~m}, 3 \mathrm{H}), 4.05(\mathrm{~m}, 1$ $\mathrm{H}), 3.80-3.88(\mathrm{~m}, 3 \mathrm{H}), 3.78(2 \mathrm{~s}, 6 \mathrm{H}), 2.72$ (irregular t, $2 \mathrm{H}), 2.60(\mathrm{~d}, J=10.0 \mathrm{~Hz}, 1$ $\mathrm{H}), 1.40$ (irregular t, $1 \mathrm{H}), 1.28(\mathrm{~m}, 1 \mathrm{H}), 0.50(\mathrm{~m}, 1 \mathrm{H}) ;{ }^{13} \mathrm{C} \mathrm{NMR}\left(100 \mathrm{MHz}, \mathrm{CH}_{3} \mathrm{OH}-\right.$ $\left.d_{4}\right) \delta 162.8,158.8,158.7,156.8,146.1,144.4,136.2,135.6,133.3,132.6,129.8,129.6$, 128.8, 128.0, 127.7, 127.6, 126.6, 118.2, 112.8, 97.7, 93.4, 86.6, 79.0, 71.1, 64.2, 62.9, $60.1,54.3,46.8,34.7,22.0,19.4,17.7,10.3$. FIA-APCl/MS $\mathrm{m} / \mathrm{z}$ (relative intensity) $765.1\left(\mathrm{MNa}^{+}, 0.3\right), 303\left(\mathrm{DMT}^{+}, 100\right)$. HRMS (MALDI, positive ion) calcd for $\mathrm{C}_{43} \mathrm{H}_{42} \mathrm{~N}_{4} \mathrm{O}_{8}: 743.3081\left(\mathrm{MH}^{+}\right)$, found: 743.3080. Anal. Calcd for $\mathrm{C}_{43} \mathrm{H}_{42} \mathrm{~N}_{4} \mathrm{O}_{8} \bullet 0.50 \mathrm{H}_{2} \mathrm{O}$ : C, 68.69; H, 5.76; N, 7.45. Found: C, 68.89; H, 5.94; N, 7.12.

\section{Preparation of 5}

To a solution of alcohol $4(229 \mathrm{mg}, 0.31 \mathrm{mmol})$ in $\mathrm{CH}_{2} \mathrm{Cl}_{2}(3.7 \mathrm{~mL})$ at $0{ }^{\circ} \mathrm{C}$, DIPEA (77 $\mu \mathrm{L}, 0.44 \mathrm{mmol})$ and 2-cyanoethyl diisopropylphosphoramidochloridite $(198 \mu \mathrm{L}, 0.89$ mmol) were added. After 15 min the reaction was allowed to reach room temperature and stirred for $1 \mathrm{~h}$. The reaction was quenched with $5 \% \mathrm{NaHCO}_{3}$, extracted with $\mathrm{CH}_{2} \mathrm{Cl}_{2}$, dried $\left(\mathrm{MgSO}_{4}\right)$ and concentrated. The residue was purified by silica column chromatography (hexanes/EtOAc 30:70 $+2 \% \mathrm{Et}_{3} \mathrm{~N}$ ) to give $262 \mathrm{mg}(90 \%)$ of 5 as a mixture of diastereoisomers; ${ }^{1} \mathrm{H}$ NMR $\left(400 \mathrm{MHz}, \mathrm{CDCl}_{3}\right) \delta 8.70(\mathrm{~d}, J=7.6 \mathrm{~Hz}, 1 \mathrm{H})$, 8.61 (bs, 1H), 7.90-7.89 (m, $2 \mathrm{H}), 7.63-7.21$ (m, $13 \mathrm{H}), 6.91-6.89$ (m, $4 \mathrm{H}), 5.12-4.76$ $(\mathrm{m}, 4 \mathrm{H}), 4.24-4.09(\mathrm{~m}, 3 \mathrm{H}), 3.99(\mathrm{~m}, 1 \mathrm{H}), 3.86(\mathrm{~m}, 6 \mathrm{H}), 3.73-3.52(\mathrm{~m}, 4 \mathrm{H}), 2.83-$ $2.49(\mathrm{~m}, 5 \mathrm{H}), 1.55-1.20(\mathrm{~m}, 14 \mathrm{H}), 0.55(\mathrm{~m}, 1 \mathrm{H}) .{ }^{13} \mathrm{C} \mathrm{NMR}\left(100 \mathrm{MHz}, \mathrm{CDCl}_{3}\right) \delta$ 161.7 , 161.6, 158.6, 158.6, 158.5, 144.2, 144.1, 135.9, 135.8, 135.5, 133.0, 132.9, $130.1,130.0,129.9,129.9,128.9,128.3,128.1,128.0,127.9,127.5,118.5,118.2$, $117.6,117.5,113.3,113.2,95.0(\mathrm{~d}, J=4.6 \mathrm{~Hz}), 94.7,86.7,86.6,79.1-79.2(\mathrm{~m}), 74.0(\mathrm{~d}$, $J=14.0 \mathrm{~Hz}), 72.7(\mathrm{~d}, J=10.2 \mathrm{~Hz}), 64.0,63.9,63.8,63.7,63.1,62.9(\mathrm{~m}), 62.5,58.1$, $58.0,55.2,55.1,45.3,45.2,43.1(\mathrm{dd}, J=2.9 \mathrm{~Hz}, J=12.6 \mathrm{~Hz}), 35.0(\mathrm{~m}), 34.8(\mathrm{~m}), 25.7$, 25.6, 24.8, 24.7, 24.6, 22.9, 22.6, 20.4, 20.3, 20.1, 20.0, 18.7, 18.6, 11.8, 11.7. ${ }^{31} \mathrm{P} \mathrm{NMR}$ $\left(110 \mathrm{MHz}, \mathrm{CDCl}_{3}\right) \delta 150.8,149.0$. HR-ES-MS $[\mathrm{M}+\mathrm{H}]^{+}$Calcd. for $\mathrm{C}_{52} \mathrm{H}_{60} \mathrm{~N}_{6} \mathrm{O}_{9} \mathrm{P}$ : 943.4159, found: 943.4149 . 


\section{Solid-phase oligonucleotide synthesis}

RNA oligonucleotides were synthesized on the $0.2 \mu$ mol scale on an Applied Biosystems 394 synthesizer using 2'-O-TBDMS protected phosphoramidites $\left(\mathrm{A}^{\mathrm{Bz}}, \mathrm{G}^{\mathrm{dmf}}\right.$, $\mathrm{C}^{\mathrm{Ac}}$ and $\mathrm{U}$ ). Commercially available succinyl polystyrene functionalized with $5^{\prime}$ - $O$ DMT-2'-deoxythymidine was used as the solid support. The following solutions were used: $0.4 \mathrm{M} 1 \mathrm{H}$-tetrazole in ACN (activation); 3\% trichloroacetic acid in DCM (detritylation), acetic anhydride/pyridine/ tetrahydrofuran (1:1:8) (capping A), 10\% Nmethylimidazole in tetrahydrofuran (capping $\mathrm{B}$ ), $0.01 \mathrm{M}$ iodine in tetrahydrofuran/pyridine/water (7:2:1) (P (III) to $\mathrm{P}$ (V) oxidation; for the unmodified sense and guide (6, wt) oligonucleotides), $10 \%$ tert-butyl hydroperoxide in acetonitrile/water (96:4) (P (III) to P (V) oxidation; for the modified guide strands 7 and 8). The coupling time was $15 \mathrm{~min}$. All oligonucleotides were synthesized in DMT-ON mode.

\section{Deprotection and purification of unmodified sense and guide (6, wt) oligonucleotides}

After the solid-phase synthesis, the solid support was transferred to a screw-cap glass vial and incubated at $55^{\circ} \mathrm{C}$ for $1 \mathrm{~h}$ with $1.5 \mathrm{~mL}$ of $\mathrm{NH}_{3}$ solution $(33 \%)$ and $0.5 \mathrm{~mL}$ of ethanol. The vial was then cooled on ice and the supernatant was transferred into a $2 \mathrm{~mL}$ eppendorf tube. The solid support and vial were rinsed with $50 \%$ ethanol $(2 \times 0.25 \mathrm{~mL})$. The combined solutions were evaporated to dryness using an evaporating centrifuge. The residue that was obtained was dissolved in a total volume of $85 \mu \mathrm{L}$ of $1 \mathrm{M}$ TBAF in THF and rocked at room temperature for $12 \mathrm{~h}$. Then, $85 \mu \mathrm{L}$ of $1 \mathrm{M}$ triethylammonium acetate (TEAA) and $330 \mu \mathrm{L}$ of water were added to the solution. The oligonucleotide was desalted on a NAP- 5 column using water as the eluent and evaporated to dryness. The oligonucleotide was purified by HPLC (DMT-ON). Column: Nucleosil 120-10 $\mathrm{C}_{18}$ (250x4 mm); 20 min linear gradient from $15 \%$ to $80 \% \mathrm{~B}$ and $5 \mathrm{~min} 80 \% \mathrm{~B}$, flow rate 3 $\mathrm{mL} / \mathrm{min}$; solution $\mathrm{A}$ was $5 \% \mathrm{ACN}$ in $0.1 \mathrm{M}$ aqueous TEAA and $\mathrm{B} 70 \% \mathrm{ACN}$ in $0.1 \mathrm{M}$ aqueous TEAA.

The pure fractions were combined and evaporated to dryness. The residue that was obtained was treated with $1 \mathrm{~mL}$ of $80 \% \mathrm{AcOH}$ solution and incubated at room temperature for $30 \mathrm{~min}$. The deprotected oligonucleotide was desalted on a NAP-10 column using water as the eluent. All oligonucleotides were quantified by absorption at $260 \mathrm{~nm}$ and confirmed by MALDI mass spectrometry.

\section{Deprotection and purification of modified oligonucleotides 7 and 8}

After the solid-phase synthesis, the solid support was transferred to a screw-cap glass vial and incubated at $35^{\circ} \mathrm{C}$ for $24 \mathrm{~h}$ with $1.5 \mathrm{~mL}$ of $\mathrm{NH}_{3}$ solution $(33 \%)$ and $0.5 \mathrm{~mL}$ of ethanol. The vial was then cooled on ice and the supernatant was transferred into a $2 \mathrm{~mL}$ eppendorf tube. The solid support and vial were rinsed with $50 \%$ ethanol $(2 \times 0.25 \mathrm{~mL})$. The combined solutions were evaporated to dryness using an evaporating centrifuge. The residue that was obtained was dissolved in a mixture formed by $10 \mu \mathrm{L}$ of $n$ propylamine, $1 \mu \mathrm{L}$ bis(2-mercaptoethyl) ether and of $100 \mu \mathrm{L}$ of $1 \mathrm{M}$ TBAF in THF and rocked at room temperature for $24 \mathrm{~h}$. Then, $100 \mu \mathrm{L}$ of $1 \mathrm{M}$ triethylammonium acetate (TEAA) and $289 \mu \mathrm{L}$ of water were added to the solution. The oligonucleotide was 
desalted on a NAP-5 column using water as the eluent and evaporated to dryness. The oligonucleotide was purified by HPLC (DMT-ON). Column: Nucleosil 120-10 $\mathrm{C}_{18}$ (250x4 mm); 20 min linear gradient from $15 \%$ to $80 \% \mathrm{~B}$ and $5 \mathrm{~min} 80 \% \mathrm{~B}$, flow rate 3 $\mathrm{mL} / \mathrm{min}$; solution $\mathrm{A}$ was $5 \% \mathrm{ACN}$ in $0.1 \mathrm{M}$ aqueous TEAA and $\mathrm{B} 70 \% \mathrm{ACN}$ in $0.1 \mathrm{M}$ aqueous TEAA.

The pure fractions were combined and evaporated to dryness. The residue that was obtained was treated with $1 \mathrm{~mL}$ of $80 \% \mathrm{AcOH}$ solution and incubated at room temperature for $30 \mathrm{~min}$. The deprotected oligonucleotide was desalted on a NAP-10 column using water as the eluent. All oligonucleotides were quantified by absorption at $260 \mathrm{~nm}$ and confirmed by MALDI mass spectrometry.

\section{General procedure for enzymatic digestion of oligonucleotides}

Each RNA oligomer (0.4 OD units at $260 \mathrm{~nm})$ was incubated with nuclease P1 (0.5 units) at $37{ }^{\circ} \mathrm{C}$ for $24 \mathrm{~h}$. Then alkaline phosphatase ( 1 unit) and buffer (50 mM Tris$\mathrm{HCl}$, pH 9.3, containing $1 \mathrm{mM} \mathrm{MgCl}_{2}, 0.1 \mathrm{mM} \mathrm{ZnCl}_{2}$ and $1 \mathrm{mM}$ spermidine, final concentrations) were added to give a total volume of $230 \mu \mathrm{L}$ and the mixture was incubated at $37^{\circ} \mathrm{C}$ for a further $24 \mathrm{~h}$. The reaction mixture was analyzed by HPLC.

\section{UV-monitored thermal denaturation studies}

Absorbance versus temperature curves of duplexes were measured at $1 \mu \mathrm{M}$ strand concentration in $15 \mathrm{mM}$ HEPES-KOH (pH 7.4), $1 \mathrm{mM} \mathrm{MgCl}_{2}$ and $50 \mathrm{mM}$ potassium acetate buffer. Experiments were performed in Teflon-stoppered $1 \mathrm{~cm}$ path lenght quartz cells on a JACSO V-650 spectrophotometer equipped with thermoprogrammer. The samples were heated to $90{ }^{\circ} \mathrm{C}$, allowed to slowly cool to $25{ }^{\circ} \mathrm{C}$, and then warmed during the denaturation experiments at a rate of $1{ }^{\circ} \mathrm{C} / \mathrm{min}$ to $85{ }^{\circ} \mathrm{C}$, monitoring absorbance $260 \mathrm{~nm}$. The data were analyzed by the denaturation curve processing program, MeltWin v. 3.0. Melting temperatures $\left(\mathrm{T}_{\mathrm{m}}\right)$ were determined by computerfit of the first derivative of absorbance with respect to $1 / \mathrm{T}$.

\section{RNAi methods}

SH-SY5Y were grown at $37{ }^{\circ} \mathrm{C}$ in Dulbecco's modified Eagle medium (DMEM; GIBCO) supplemented with 10\% fetal bovine serum (FBS), $100 \mathrm{U} / \mathrm{mL}$ penicillin and $100 \mu \mathrm{g} / \mathrm{mL}$ streptomycin. Cells were regularly passaged to mantain exponential growth. Twenty-four hours before transfection at 50-80\% confluency, mammalian cells were trypsinized and diluted 1:5 with fresh medium without antibiotics $\left(1-3 \times 10^{5}\right.$ cells $\left./ \mathrm{mL}\right)$ and transferred to 24 -well plates $(500 \mu \mathrm{L}$ per well). Two luciferase plasmids, Renilla luciferase (pRL-TK) and Firefly luciferase (pGL3) from Promega, were used as a reporter and control, respectively. Cotransfection of plasmids and siRNAs was carried out with Lipofectamine 2000 (Life Technologies) as described by the manufacturer for adherent cell lines. Per well, $1.0 \mu \mathrm{g}$ pGL3-Control, $0.1 \mu \mathrm{g}$ pRL-TK and 0.03-26 nM siRNA duplex formulated into liposomes, were applied; the final volume was $600 \mu \mathrm{L}$ per well. The cells were harvested $22 \mathrm{~h}$ after transfection, and lysed using passive lysis buffer, $100 \mu \mathrm{L}$ per well, according to the instructions of the Dual-Luciferase Reporter Assay System (Promega). The luciferase activities of the samples were measured using 
a MicroLumaPlus LB 96V (Berthold Technologies) with a delay time of $2 \mathrm{~s}$ and an integrate time of $10 \mathrm{~s}$. The following volumes were used: $20 \mu \mathrm{L}$ of sample and $30 \mu \mathrm{L}$ of each reagent (Luciferase Assay Reagent II and Stop and Glo Reagent). The inhibitory effects generated by siRNAs were expressed as normalized ratios between the activities of the reporter (Renilla) luciferase gene and the control (Firefly) luciferase gene. 

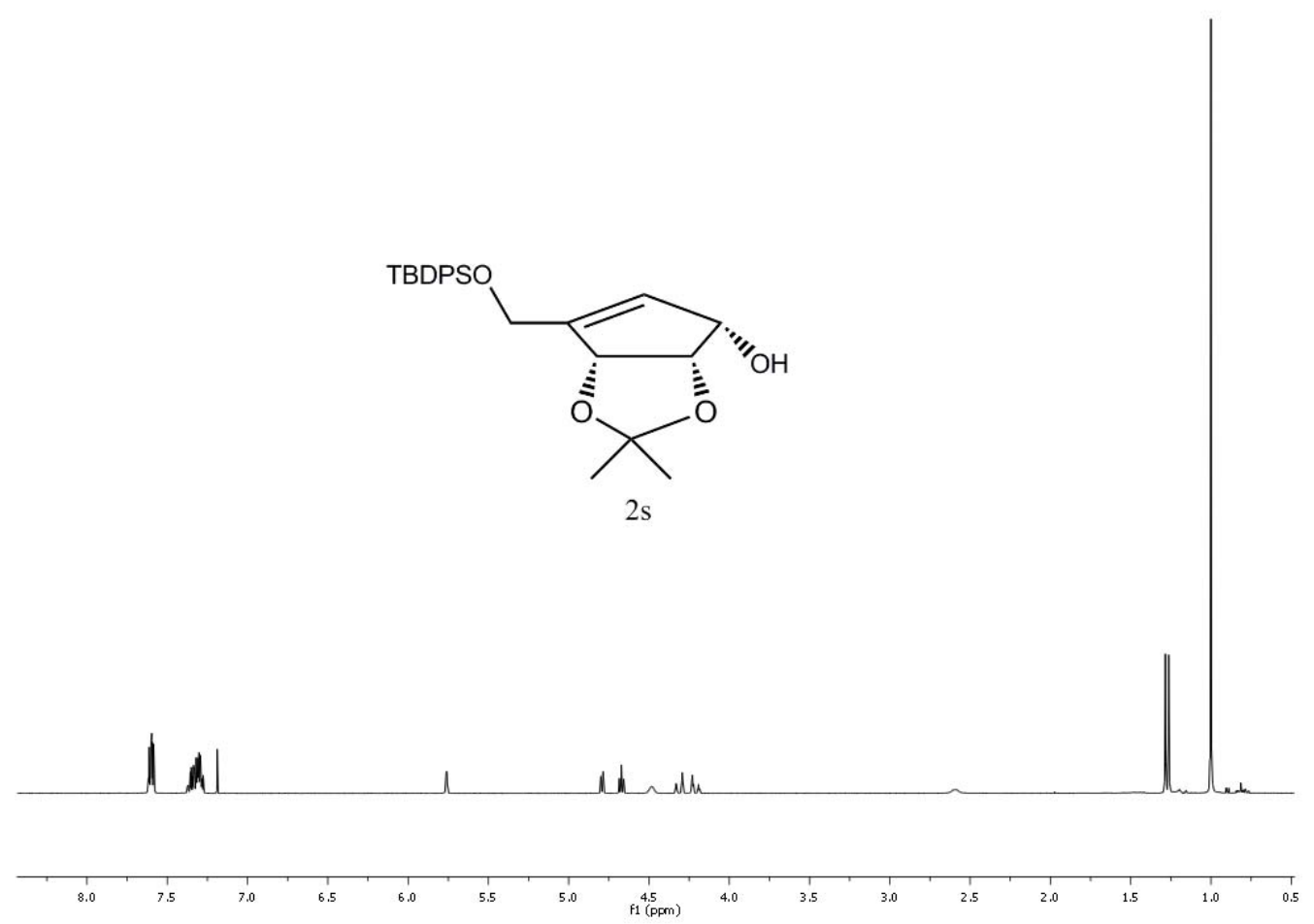

Figure S1. ${ }^{1} \mathrm{H}$-NMR spectrum of compound $2 \mathrm{~s}$

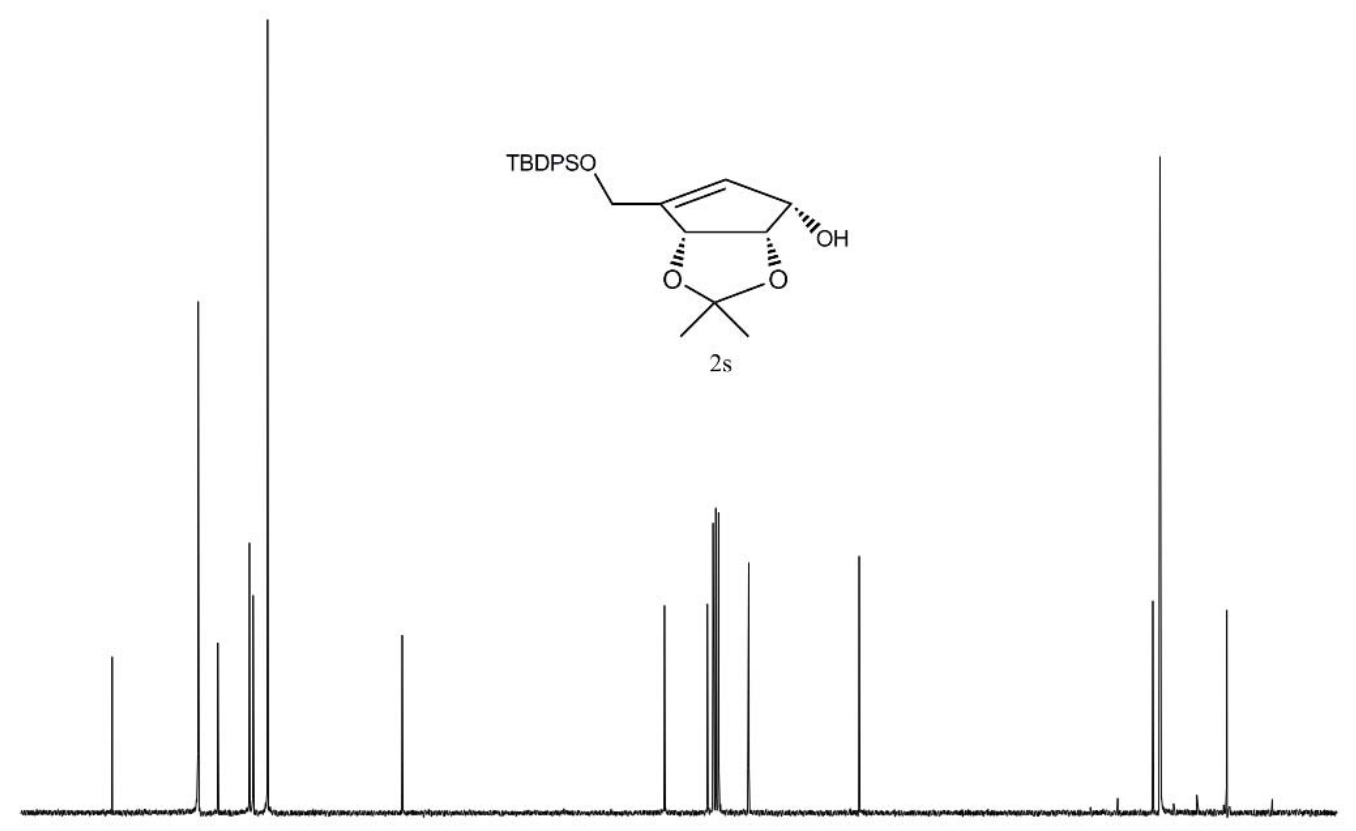

Figure S2. ${ }^{13} \mathrm{C}-\mathrm{NMR}$ spectrum of compound $2 \mathrm{~s}$ 

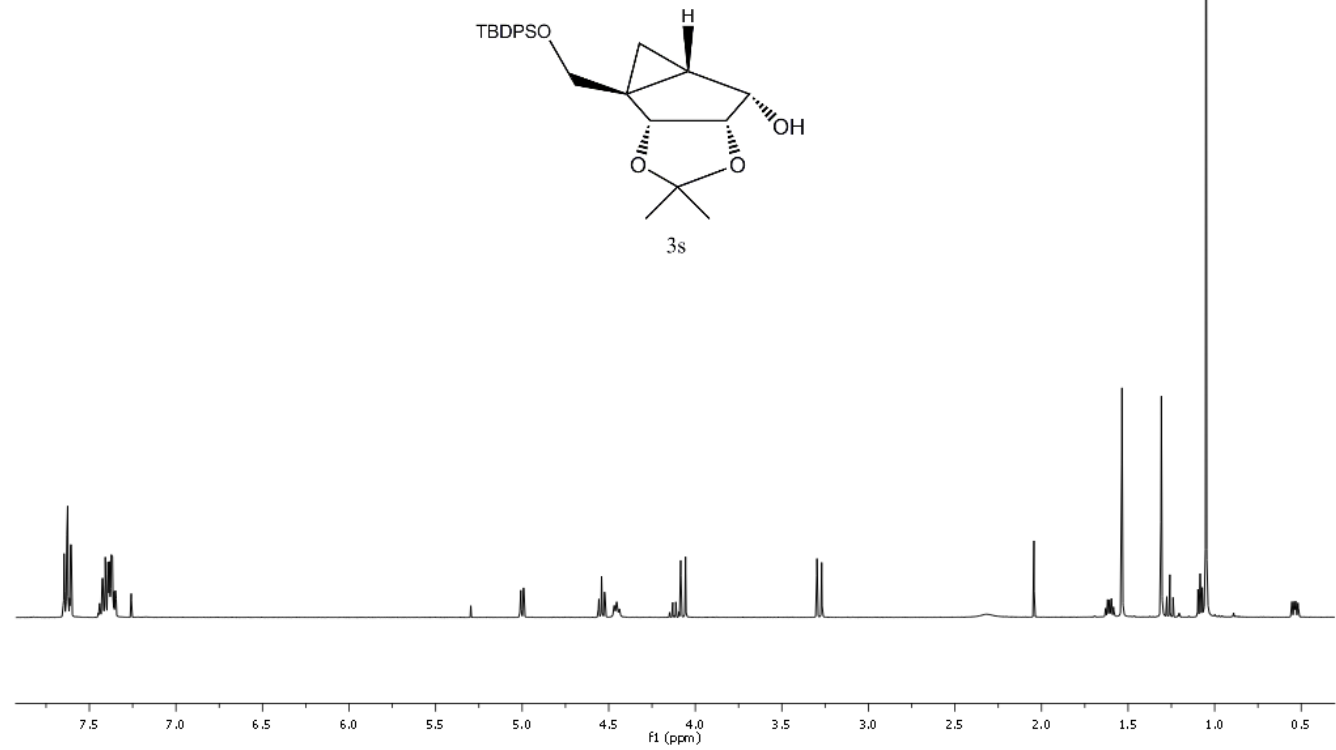

Figure S3. ${ }^{1} \mathrm{H}$-NMR spectrum of compound $3 \mathrm{~s}$

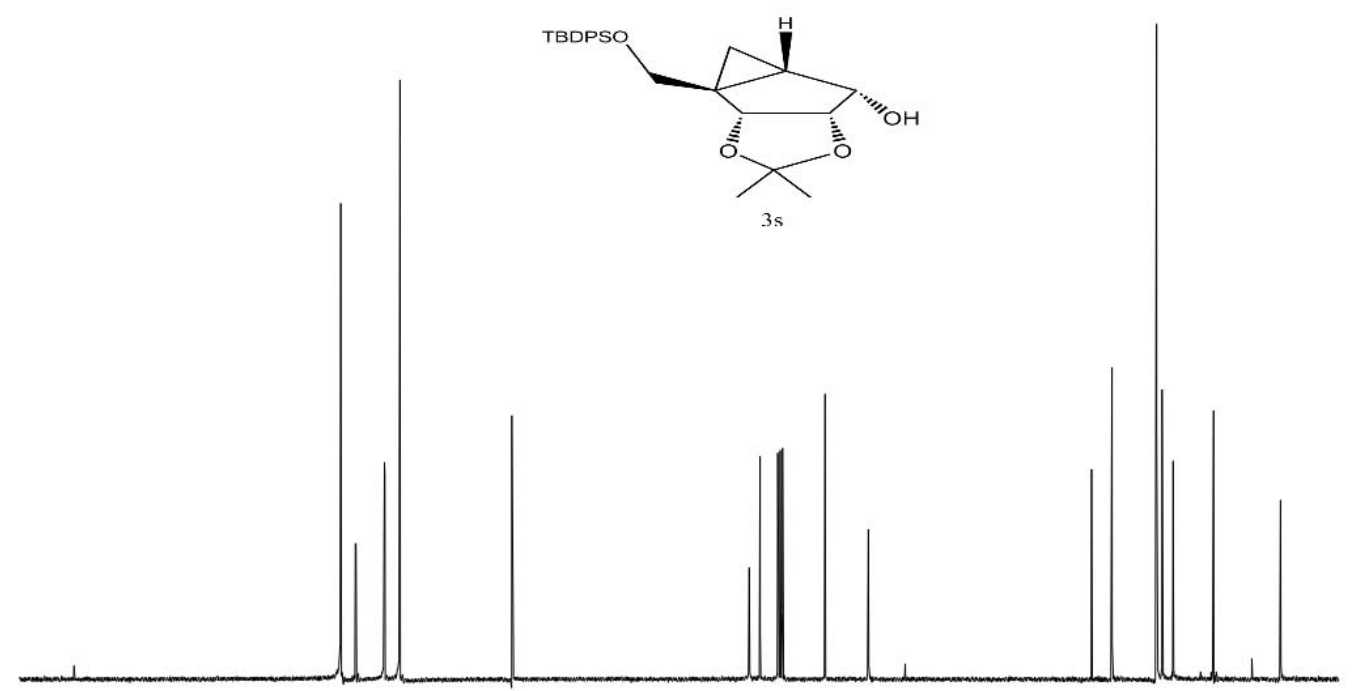

Figure S4. ${ }^{13} \mathrm{C}$-NMR spectrum of compound $3 \mathrm{~s}$ 

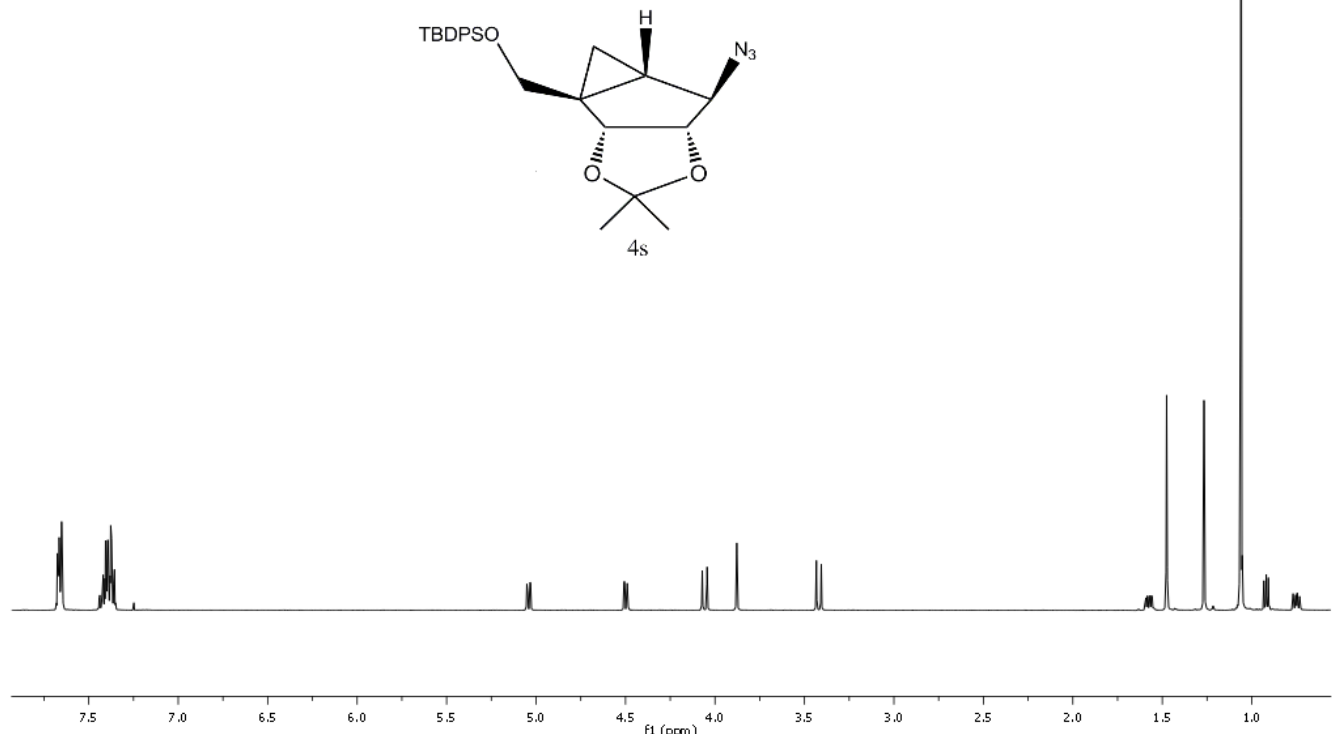

Figure S5. ${ }^{1} \mathrm{H}$-NMR spectrum of compound $4 \mathrm{~s}$

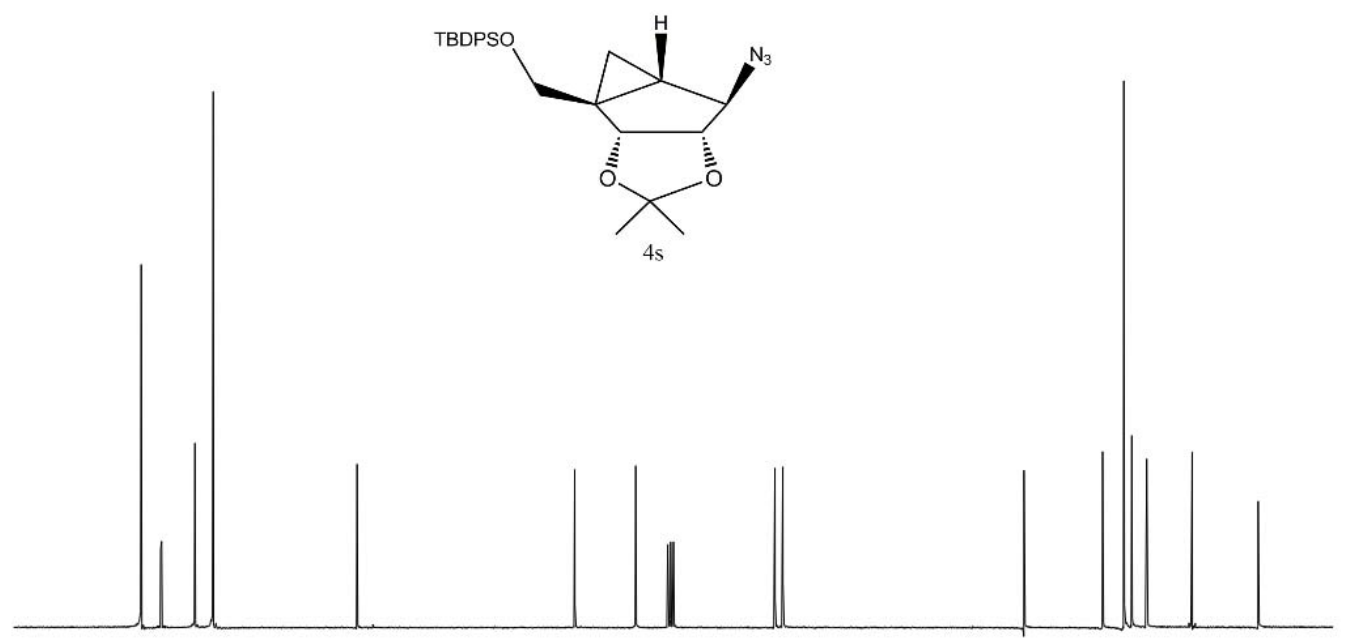

$140+130+120$ ${ }_{\mathrm{F}}^{80}(\mathrm{ppm})$

Figure S6. ${ }^{13} \mathrm{C}-\mathrm{NMR}$ spectrum of compound $4 \mathrm{~s}$ 


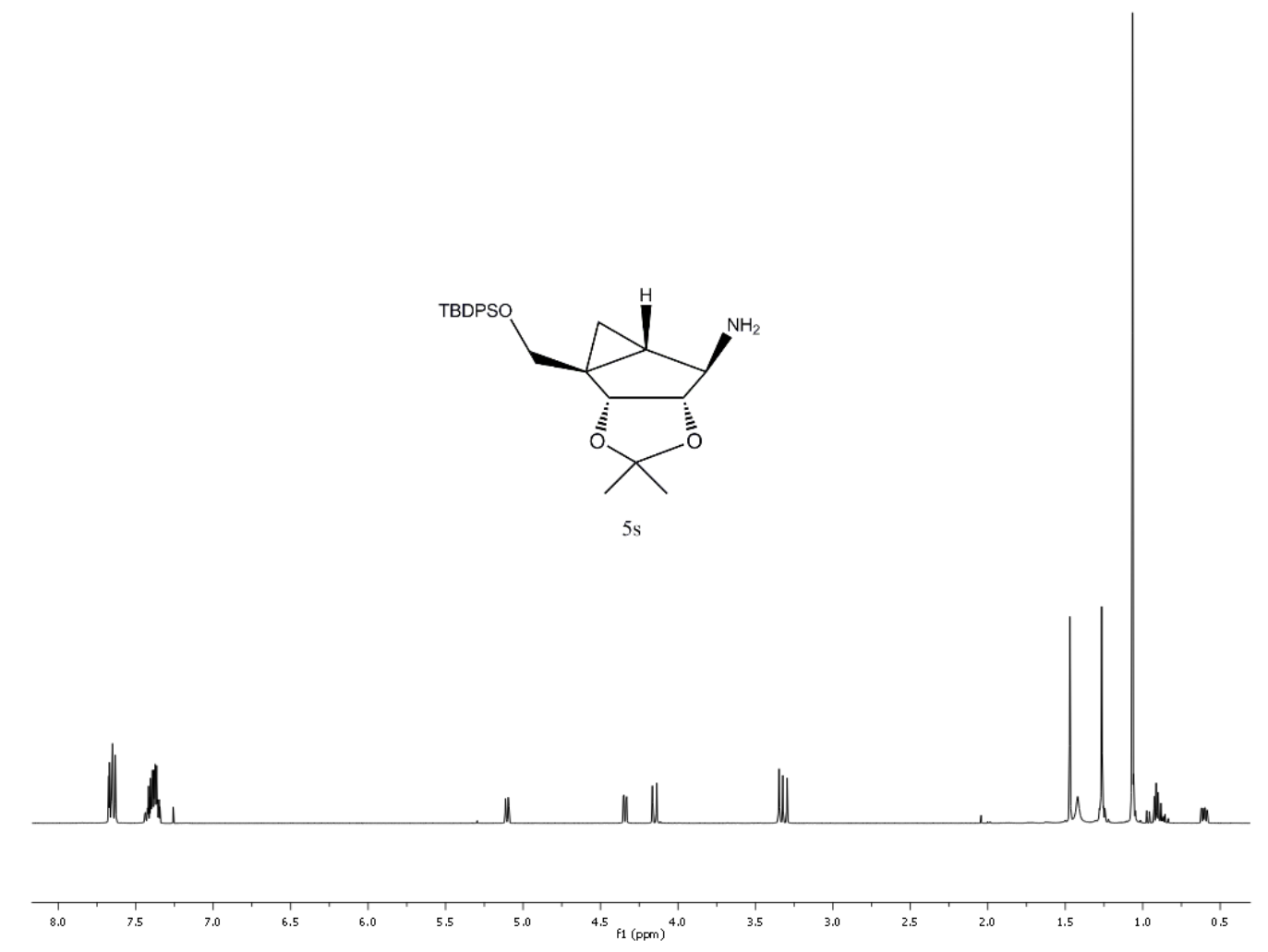

Figure S7. ${ }^{1} \mathrm{H}$-NMR spectrum of compound $5 \mathrm{~s}$

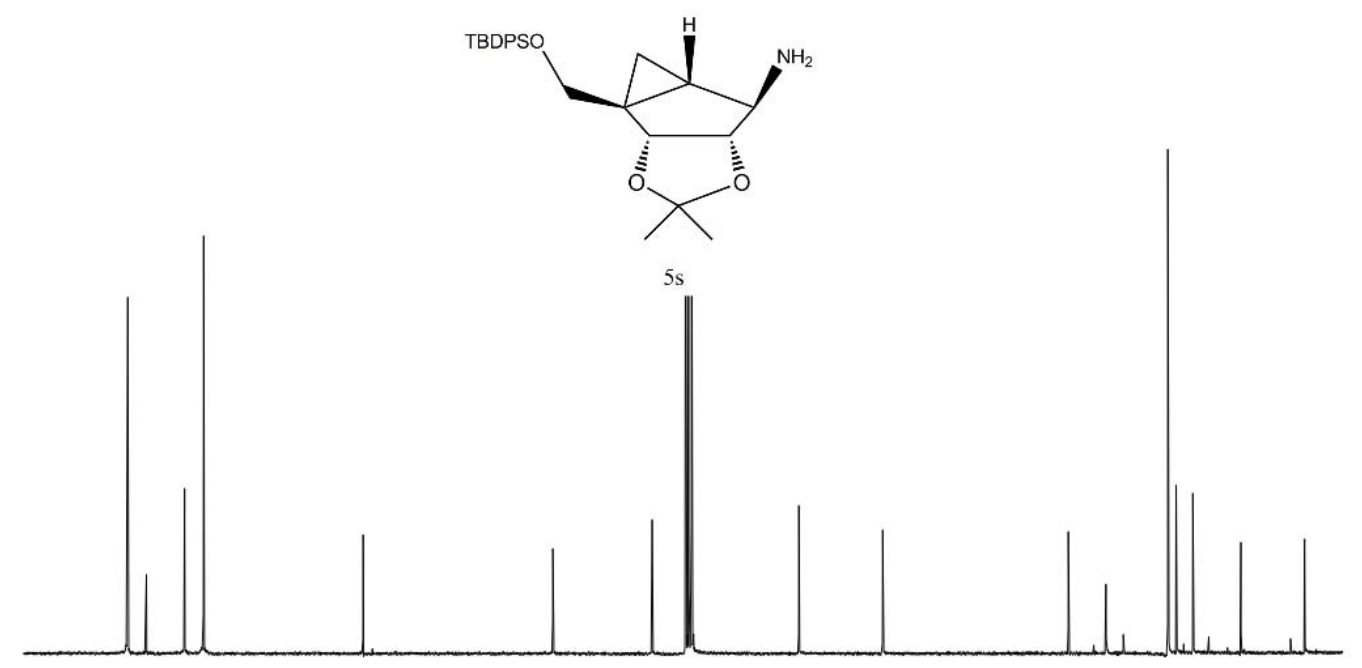

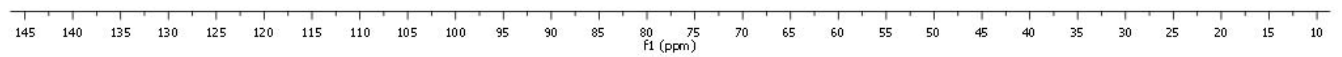

Figure S8. ${ }^{13} \mathrm{C}-\mathrm{NMR}$ spectrum of compound $5 \mathrm{~s}$ 

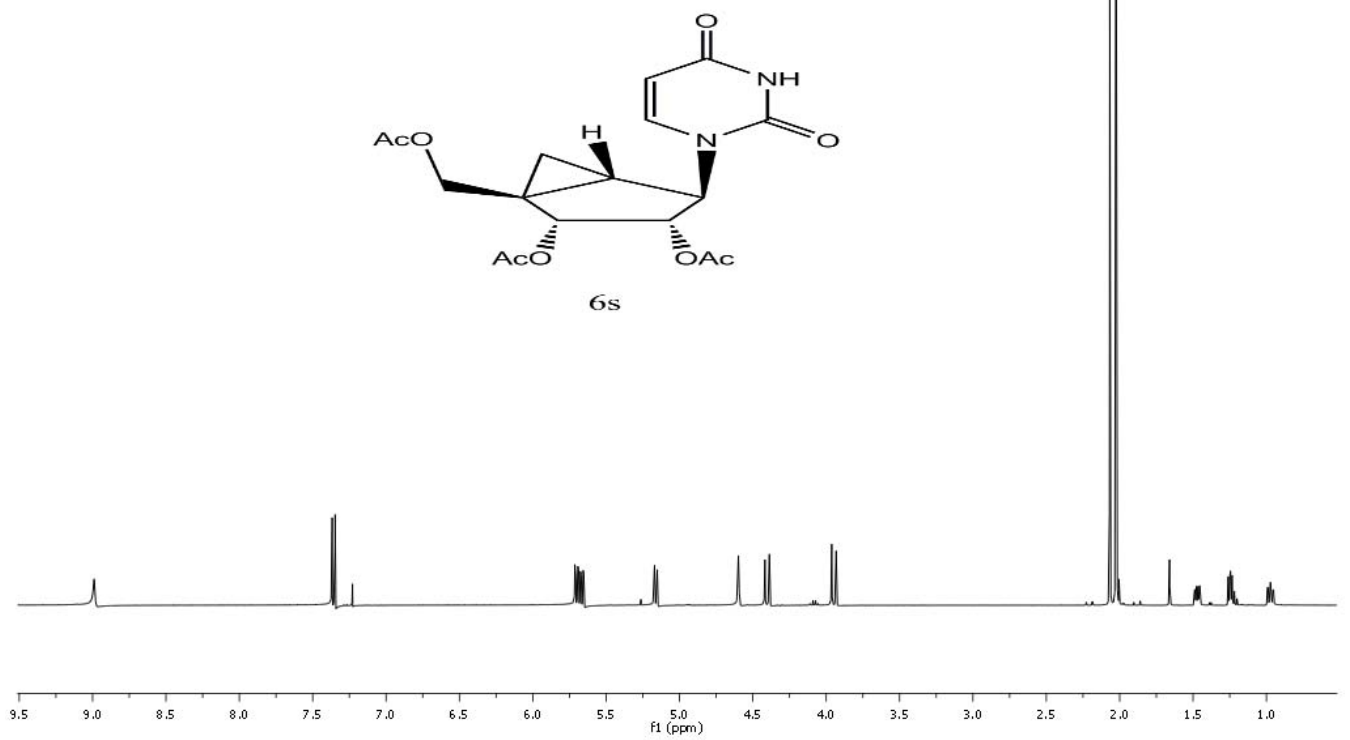

Figure S9. ${ }^{1} \mathrm{H}$-NMR spectrum of compound $6 \mathrm{~s}$

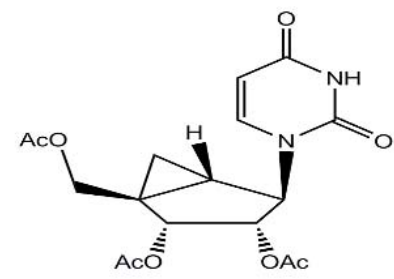

$6 \mathrm{~s}$
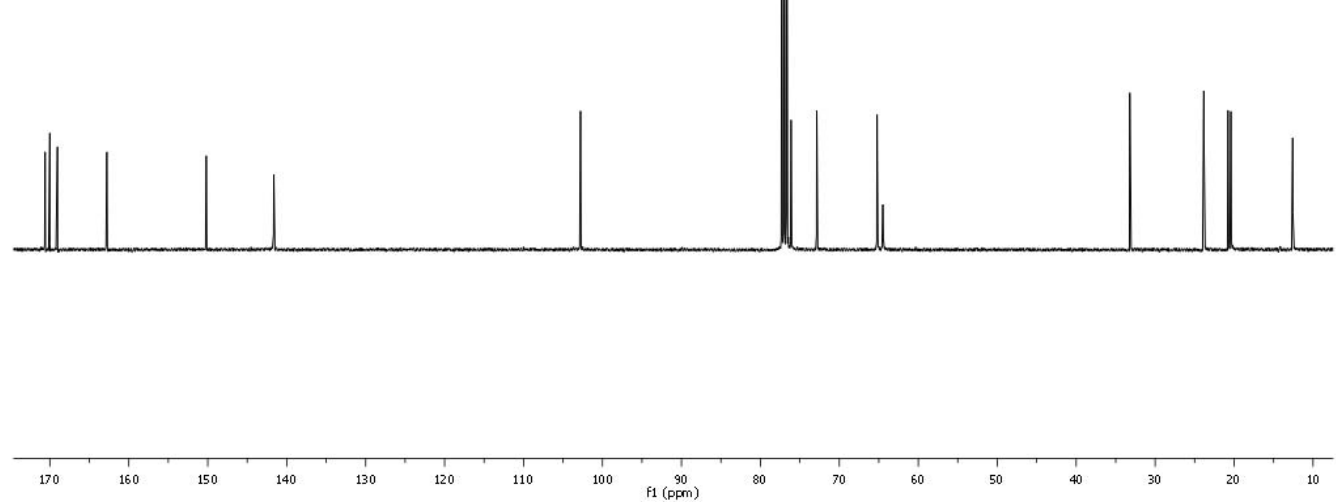

Figure S10. ${ }^{13} \mathrm{C}$-NMR spectrum of compound 6s 


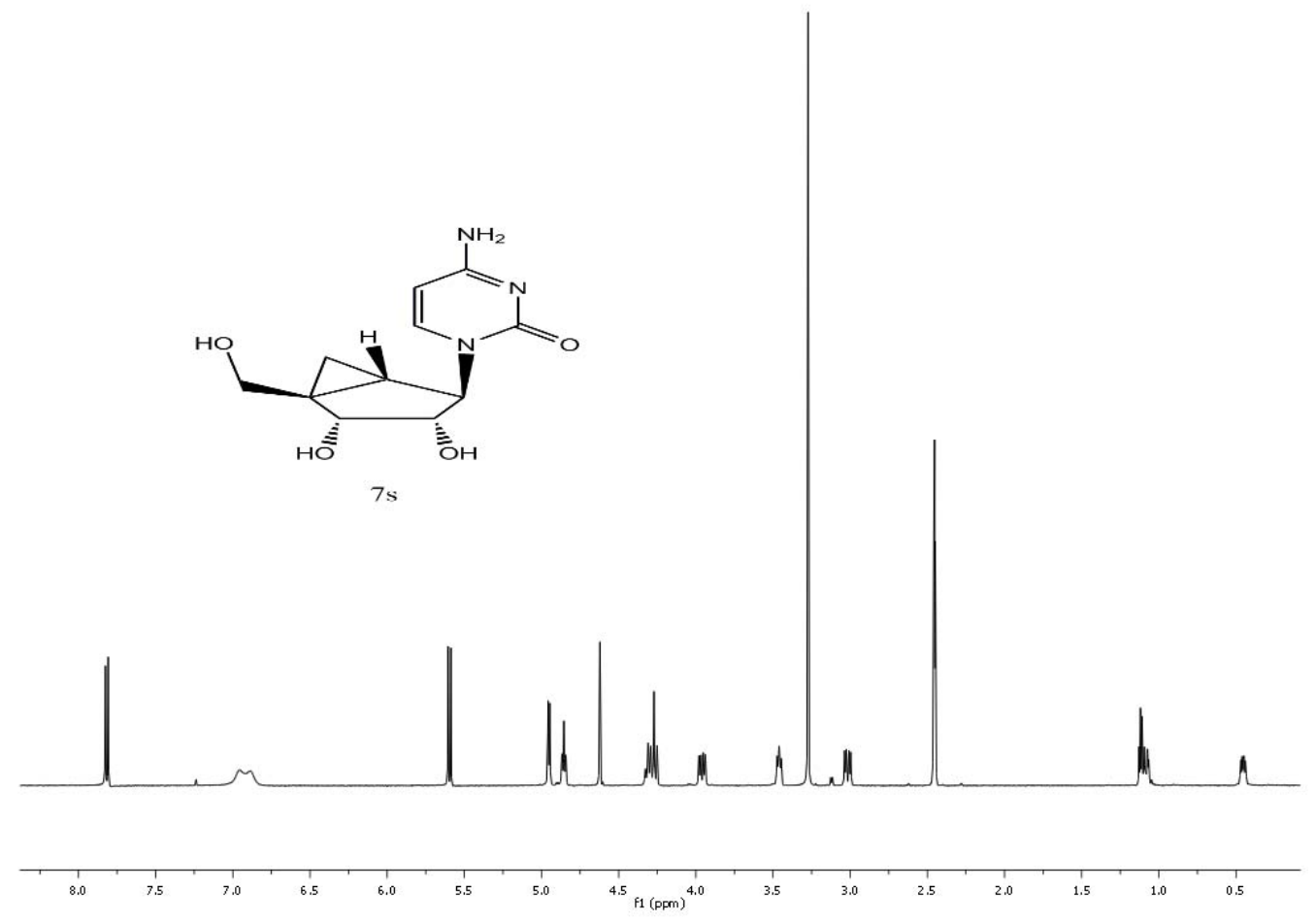

Figure S11. ${ }^{1} \mathrm{H}-\mathrm{NMR}$ spectrum of compound $7 \mathrm{~s}$
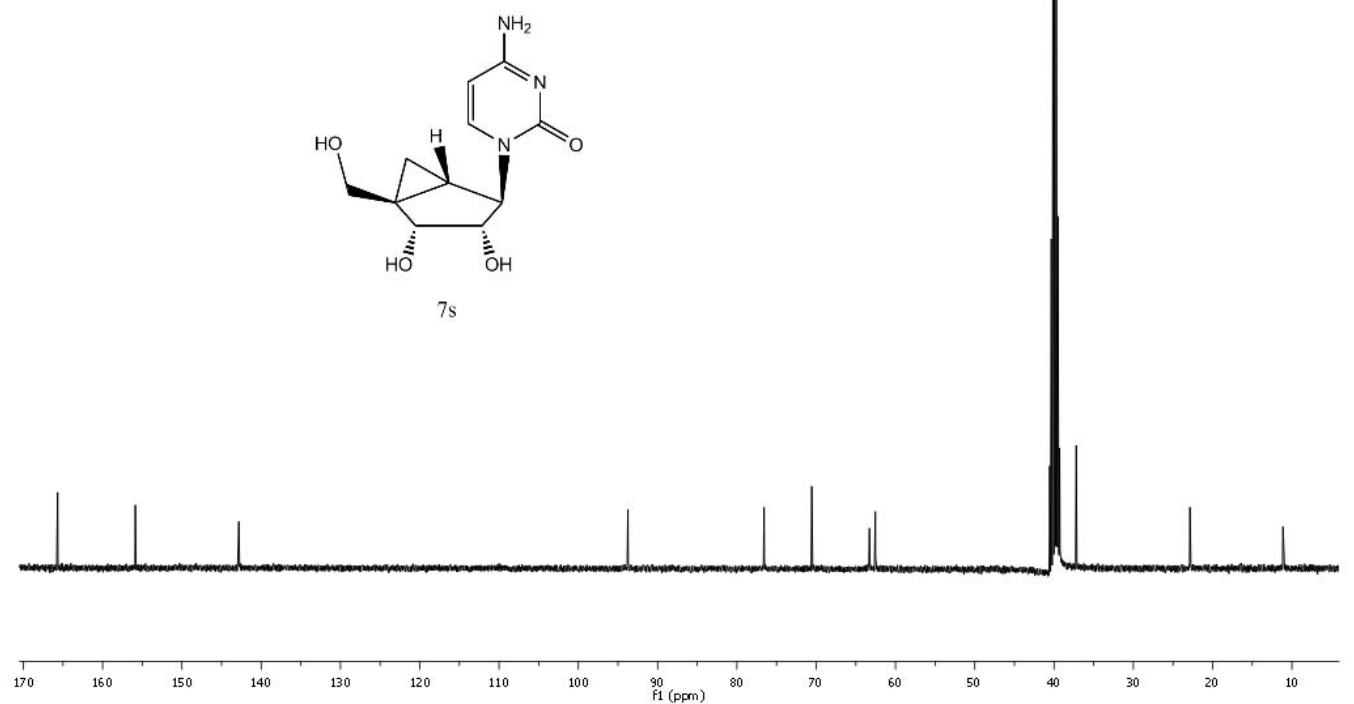

Figure S12. ${ }^{13} \mathrm{C}-\mathrm{NMR}$ spectrum of compound $7 \mathrm{~s}$ 


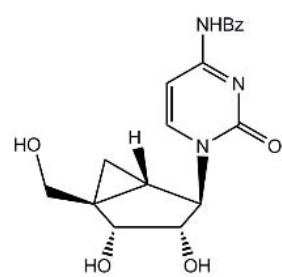

$8 \mathrm{~s}$
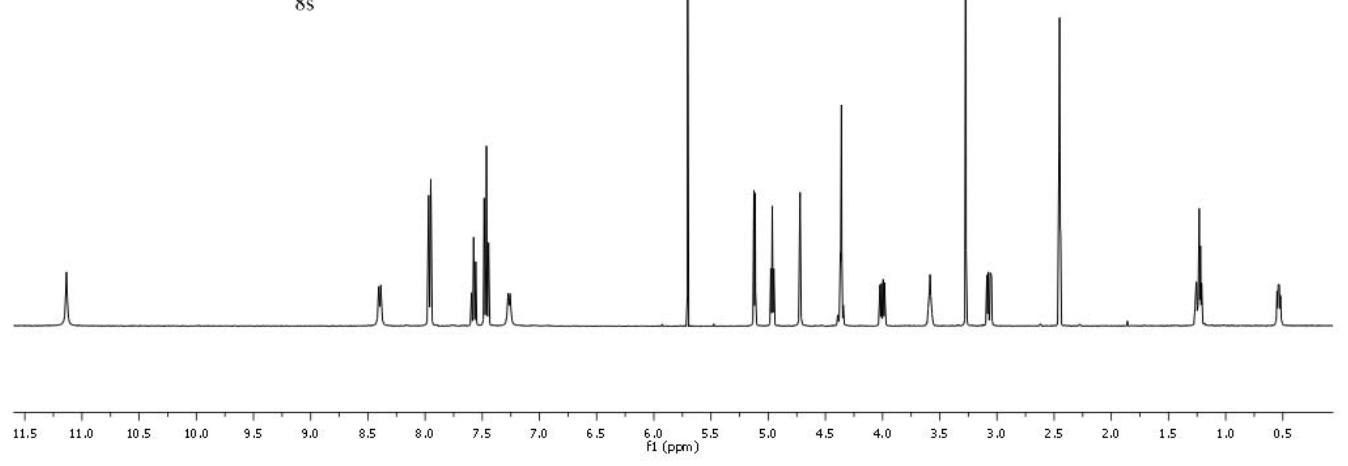

Figure S13. ${ }^{1} \mathrm{H}$-NMR spectrum of compound $8 \mathrm{~s}$
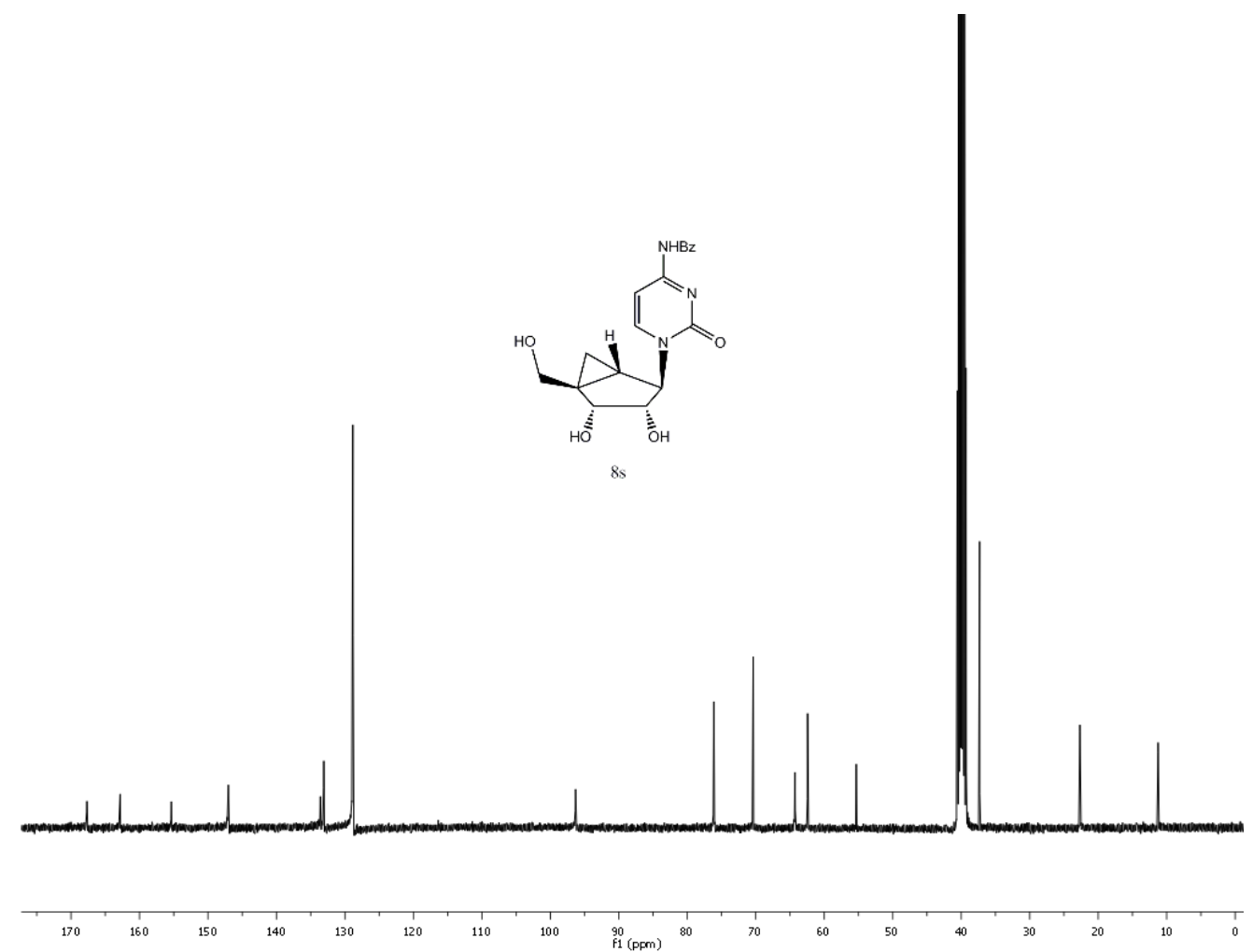

Figure S14. ${ }^{13} \mathrm{C}$-NMR spectrum of compound $8 \mathrm{~s}$ 


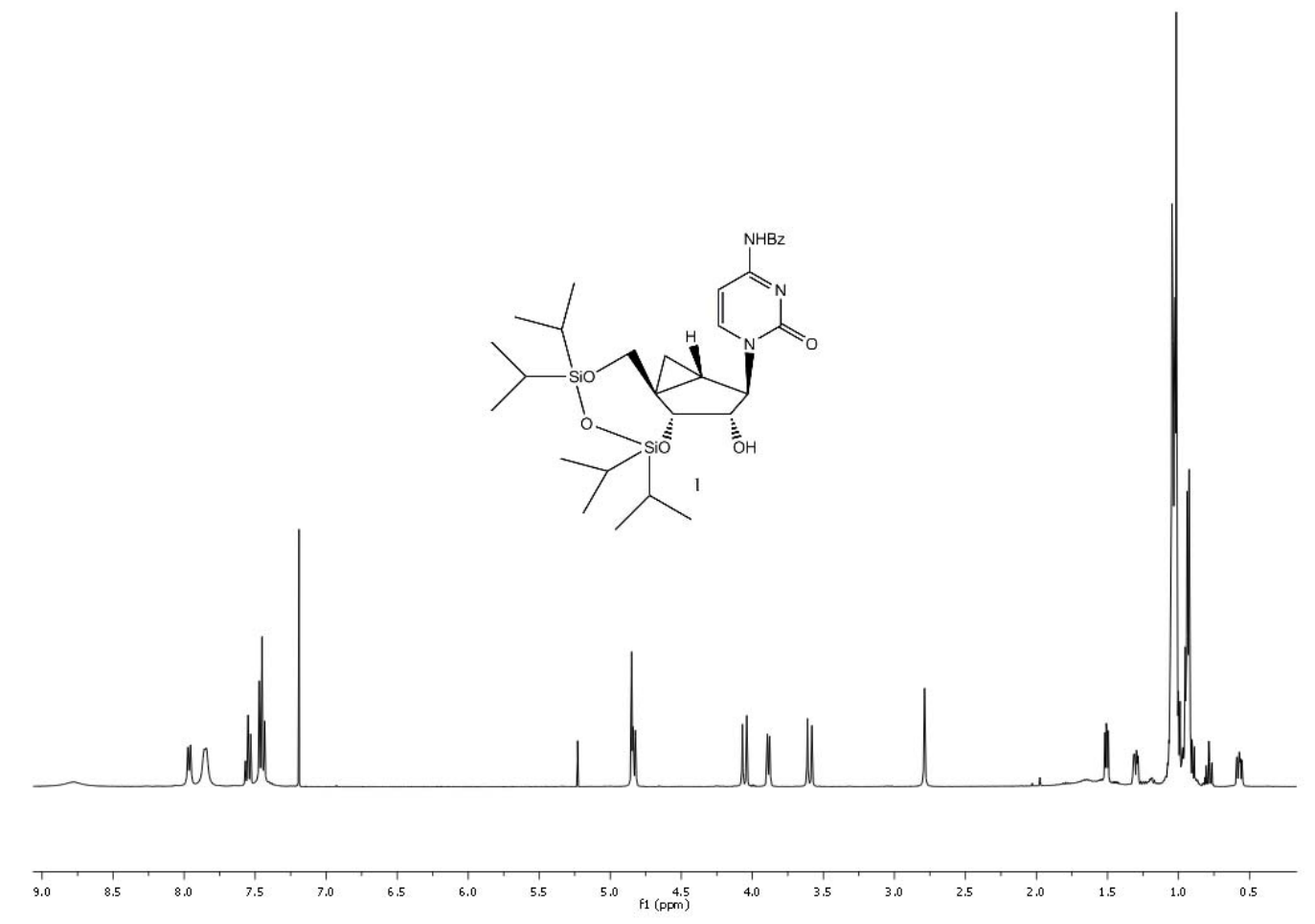

Figure S15. ${ }^{1} \mathrm{H}-\mathrm{NMR}$ spectrum of compound 1

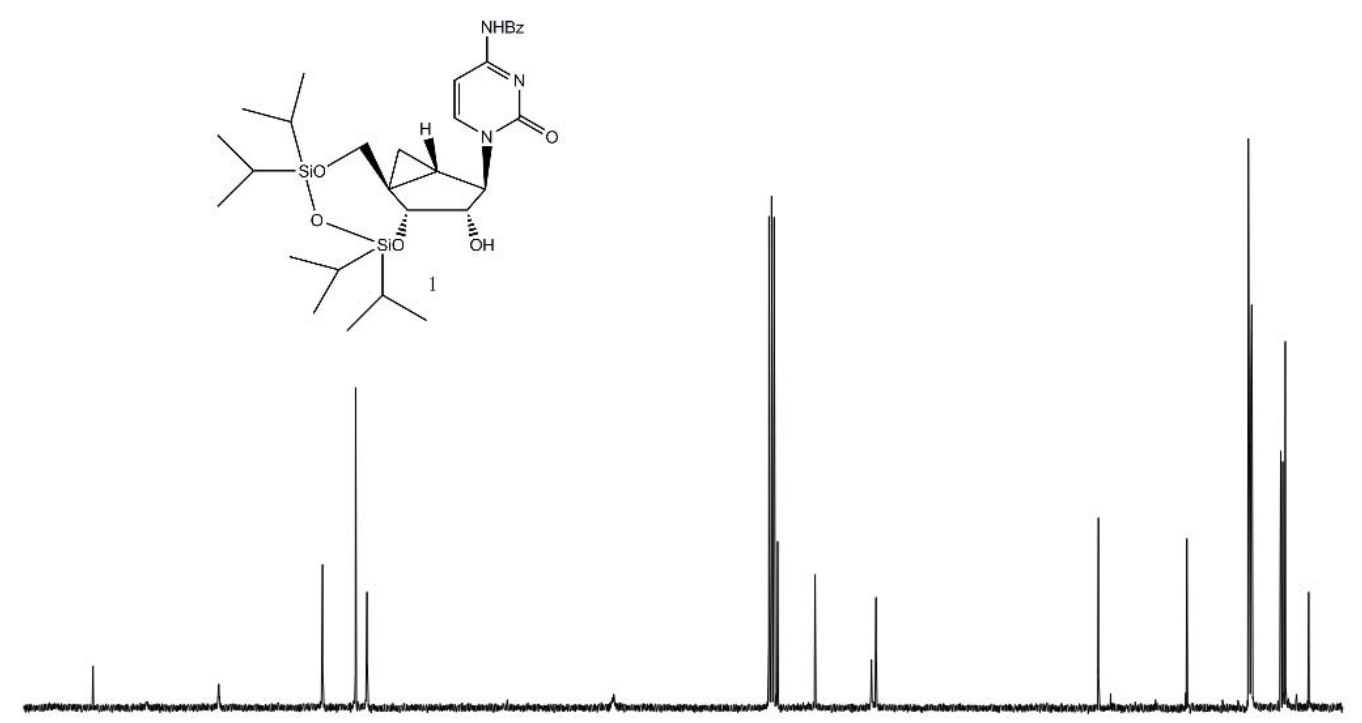

Figure S16. ${ }^{13} \mathrm{C}$-NMR spectrum of compound 1 

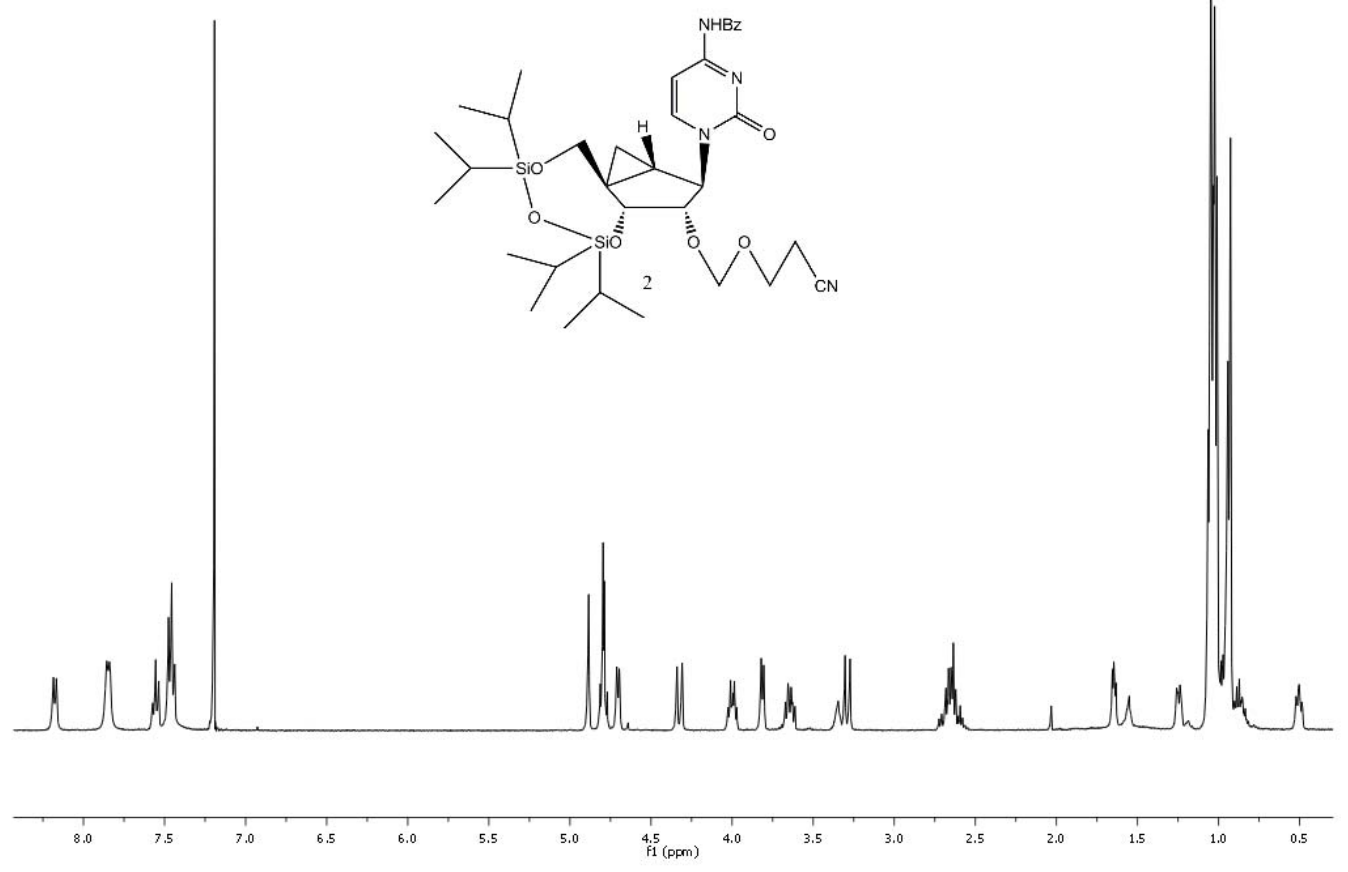

Figure S17. ${ }^{1} \mathrm{H}$-NMR spectrum of compound 2

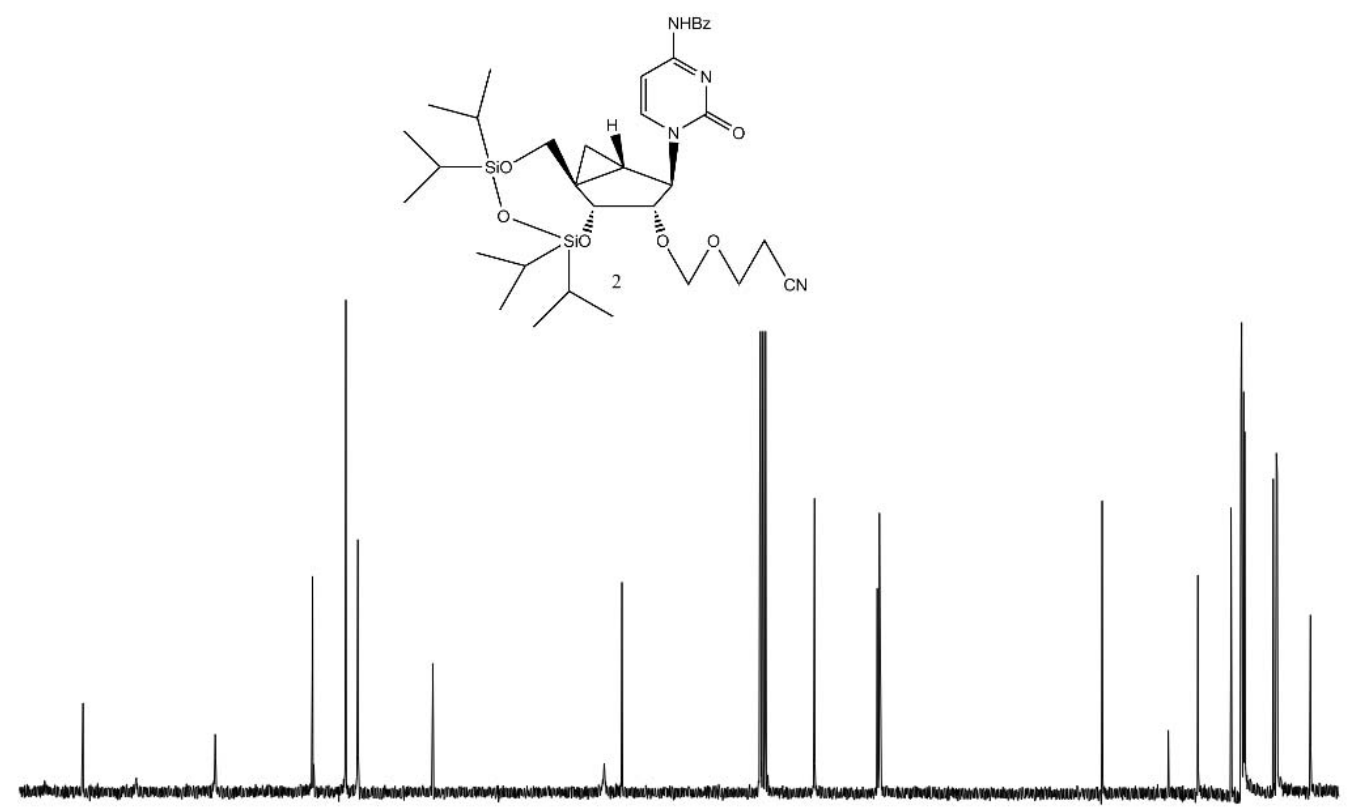

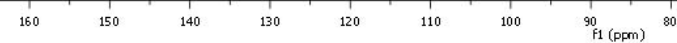

Figure S18. ${ }^{13} \mathrm{C}$-NMR spectrum of compound 2 


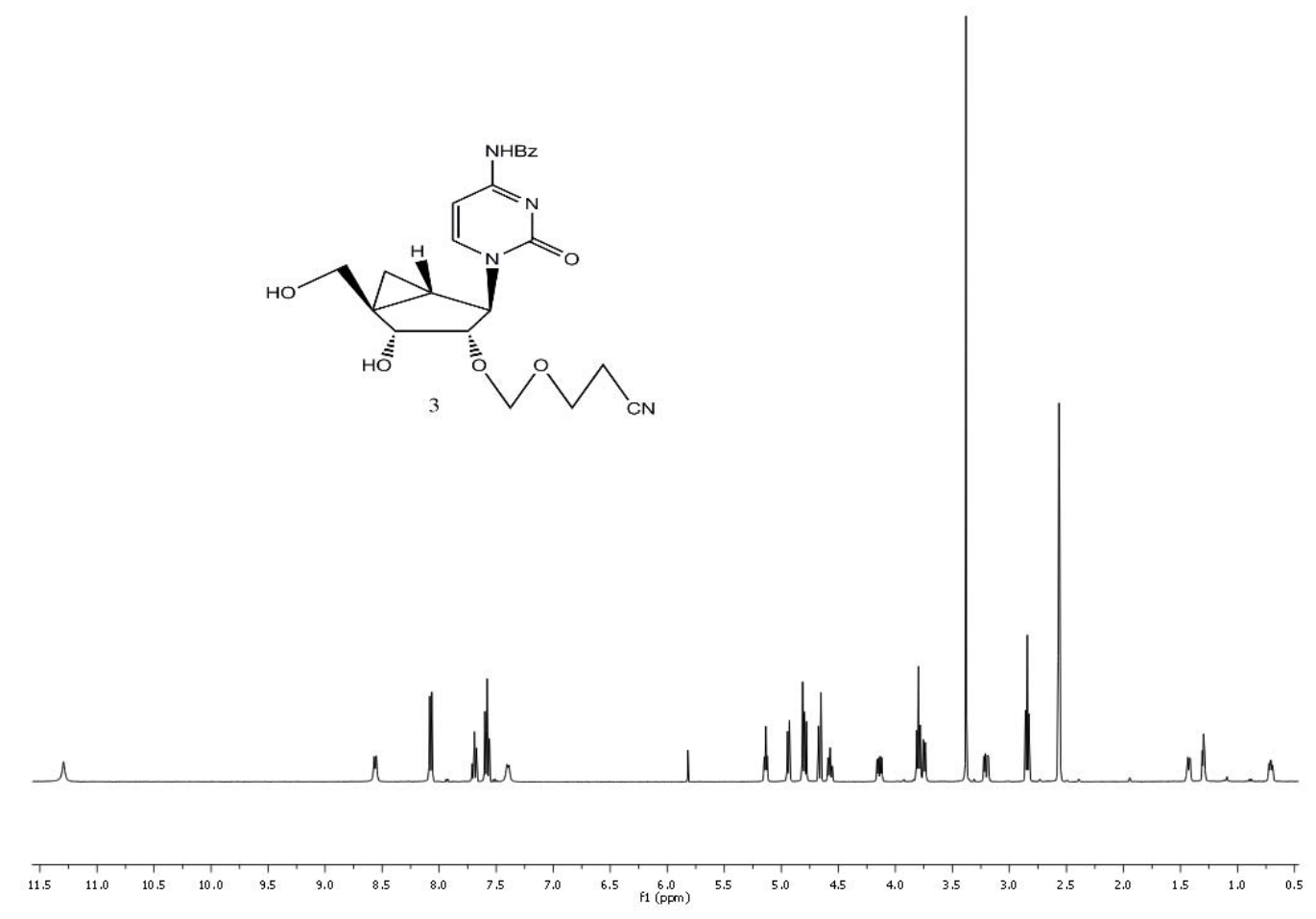

Figure S19. ${ }^{1} \mathrm{H}-\mathrm{NMR}$ spectrum of compound 3

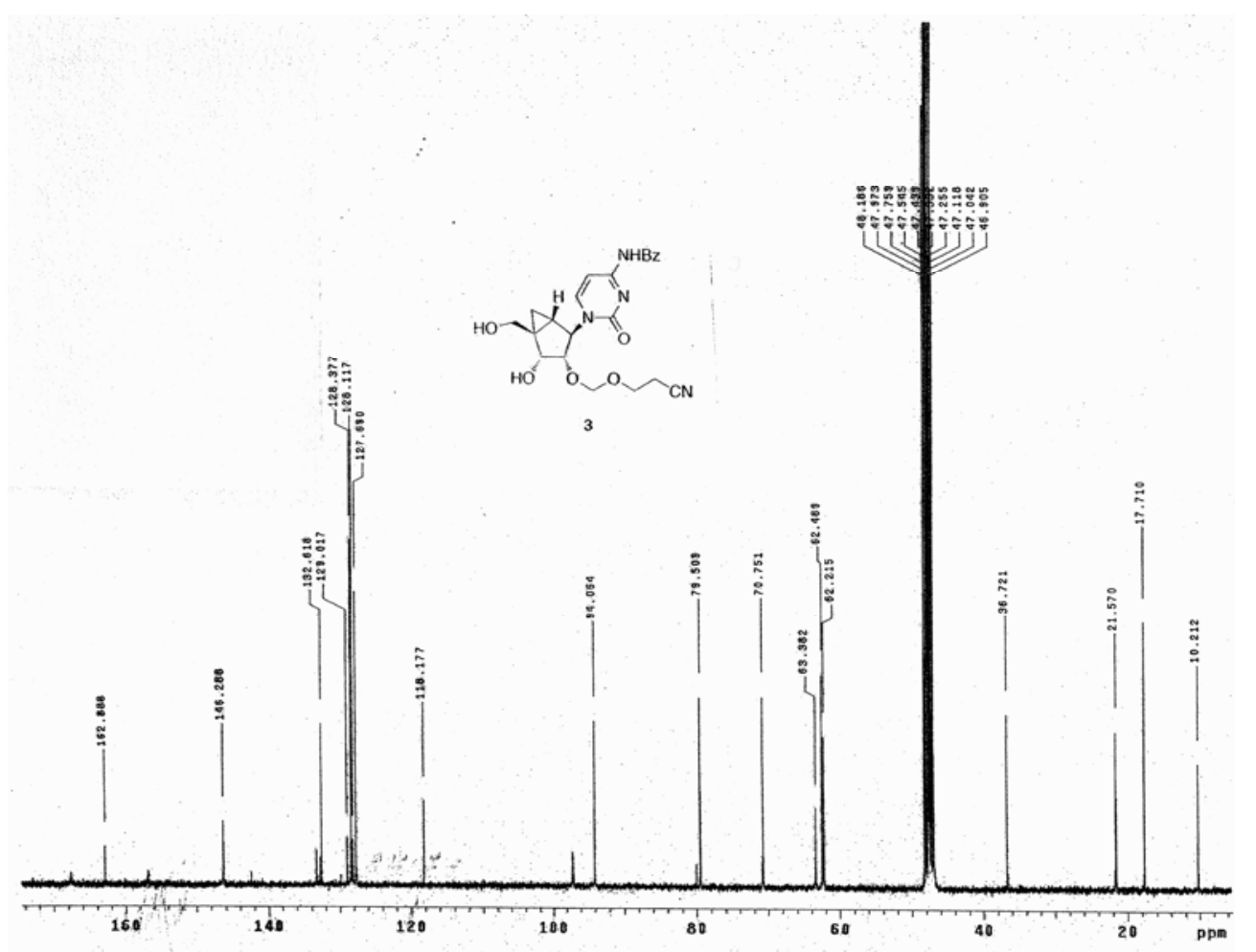

Figure S20. ${ }^{13} \mathrm{C}$-NMR spectrum of compound 3 

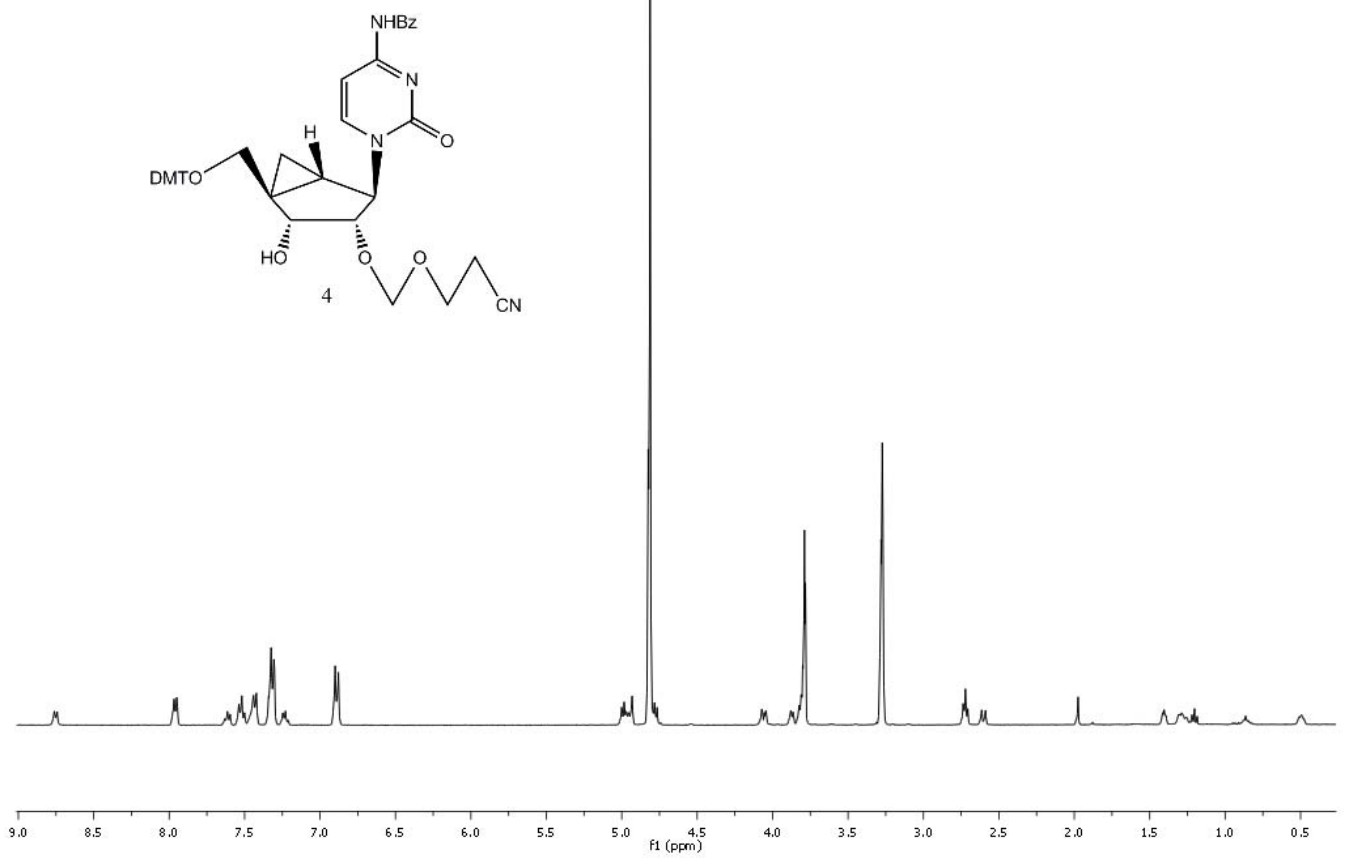

Figure S21. ${ }^{1} \mathrm{H}$-NMR spectrum of compound 4
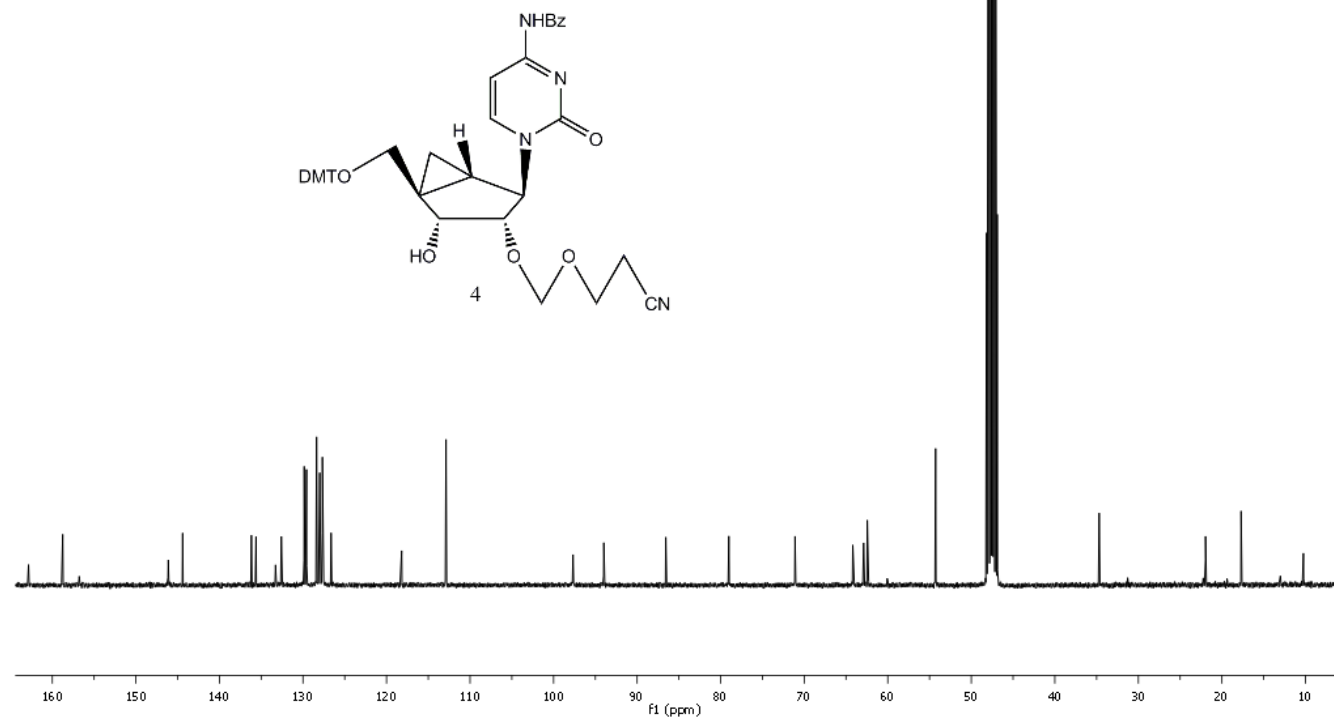

Figure S22. ${ }^{13} \mathrm{C}$-NMR spectrum of compound 4 


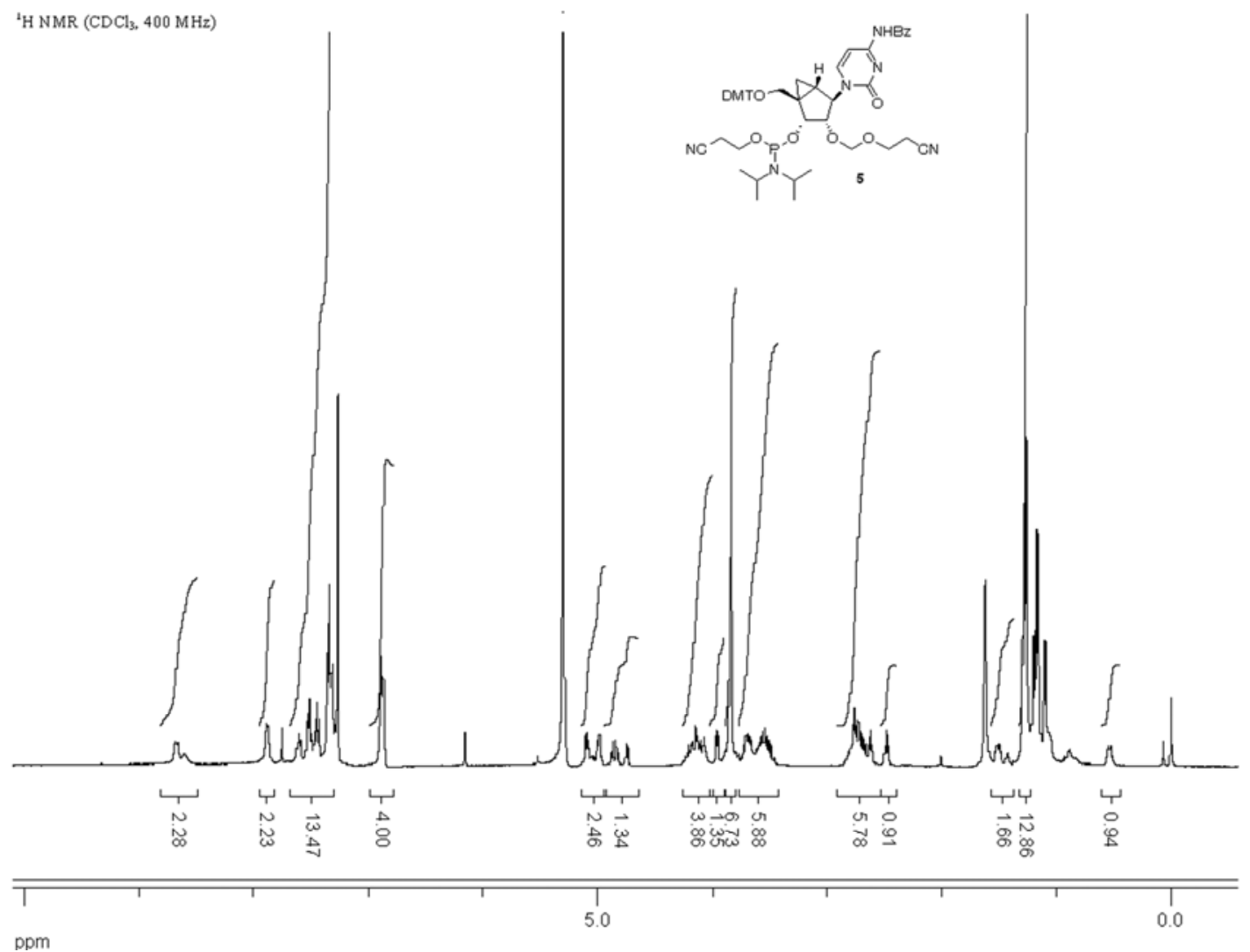

Figure S23. ${ }^{1}$ H-NMR spectrum of compound 5 


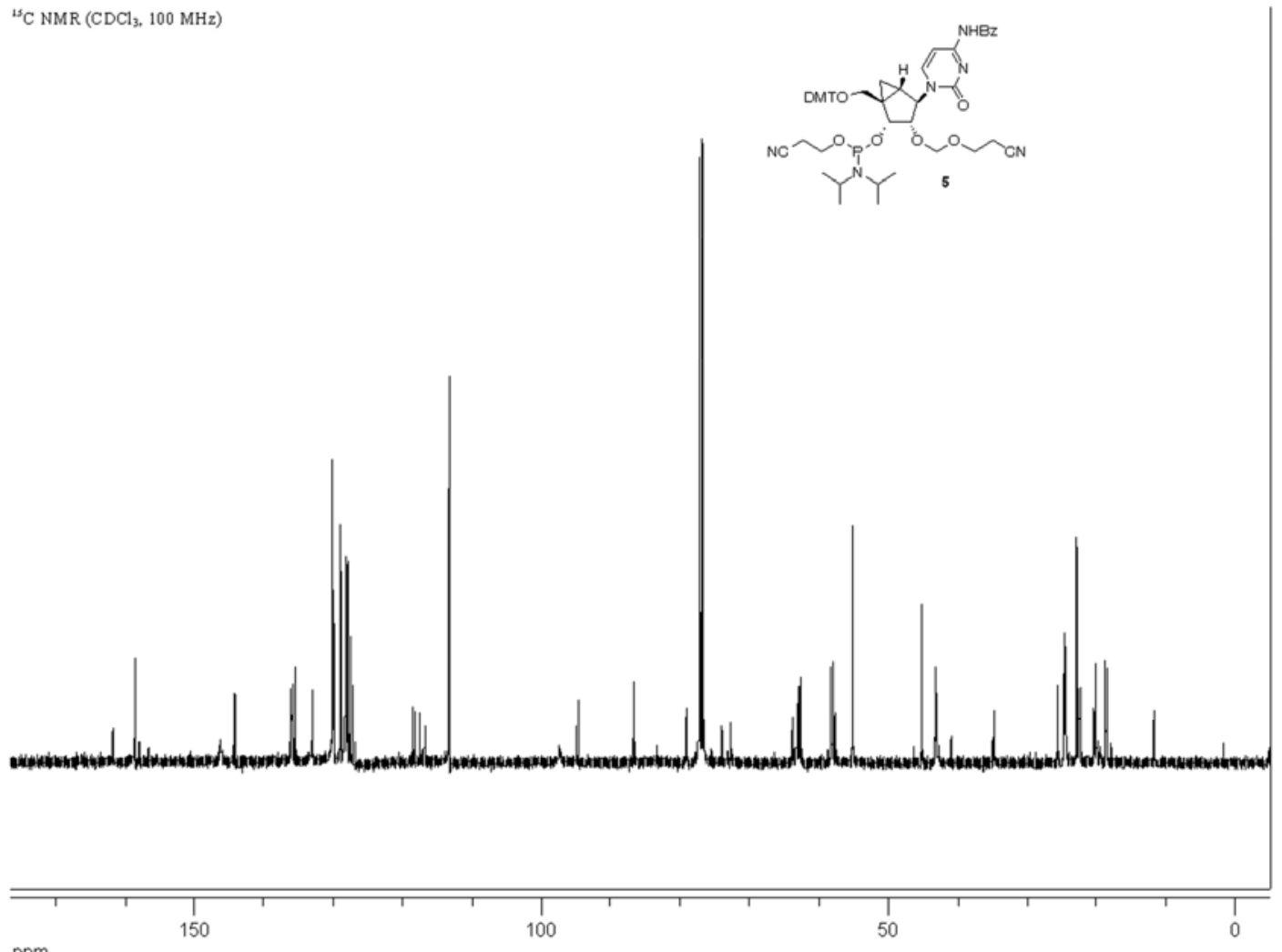

Figure S24. ${ }^{13} \mathrm{C}-\mathrm{NMR}$ spectrum of compound 5

${ }^{31} \mathrm{P}$ NMR $\left(\mathrm{CDCl}_{3}, 110 \mathrm{MHz}\right)$

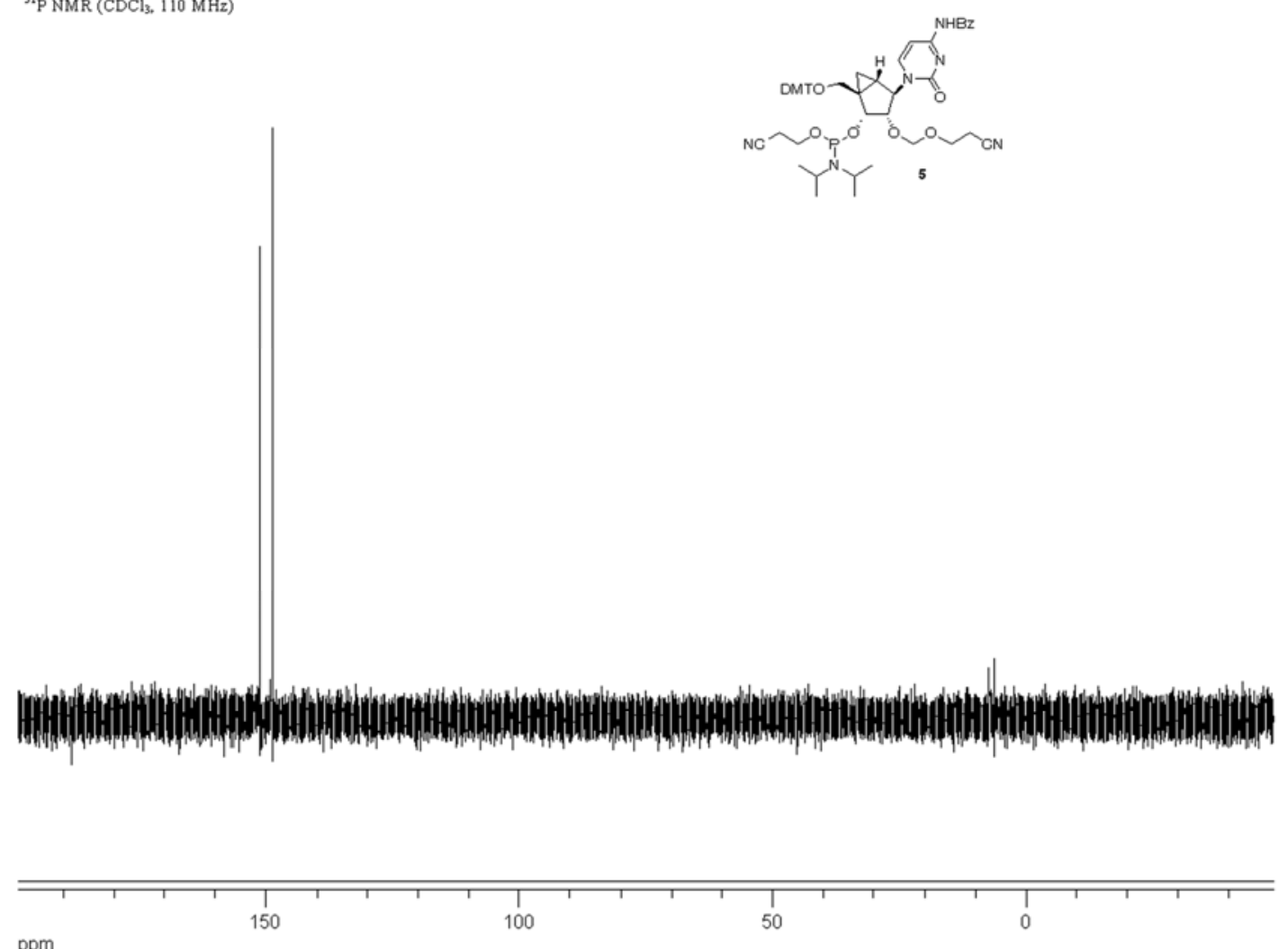

ppm

Figure S25. ${ }^{31} \mathrm{P}$-NMR spectrum of compound 5 
Table S1. MALDI-TOF mass spectra of synthesized oligonucleotides

\begin{tabular}{|c|c|c|c|}
\hline Oligonucleotide & Sequence & MW calcd. & $\begin{array}{l}\text { MW } \\
\text { found }\end{array}$ \\
\hline sense & 3'-TTAAAAAGAGGAAGAAGUCUA-5' & 6790.0 & 6787.6 \\
\hline guide, 6 (wt) & 5'-UUUUUCUCCUUCUUCAGAUTT-3' & 6423.0 & 6426.4 \\
\hline guide, 7 & 5'-UUUUUCUC ${ }^{\mathrm{N}}$ CUUCUUCAGAUTT-3' & 6431.0 & 6441.8 \\
\hline guide, 8 & 5'-UUUUUCUC ${ }^{\mathrm{N}}$ CUUCUUC $^{\mathrm{N}}$ AGAUTT-3' & 6464.6 & 6470.8 \\
\hline scr-ss & 3'-TTAGGAAAGAAAGAAAGCUAU-5' & 6790 & 6796.5 \\
\hline scr-guide & 5'-UCCUUUCUUUCUUUCGAUATT-3' & 6421.3 & 6425.4 \\
\hline
\end{tabular}

Figure S26. MALDI-TOF mass spectra of synthesized oligonucleotides

Guide strand 7 
Applied Biosystems Voyager System 2081

Voyager $\mathrm{Spec} \# 1 \Rightarrow M C \Rightarrow B C \Rightarrow N F 0.7[B P=6441.3,17247]$

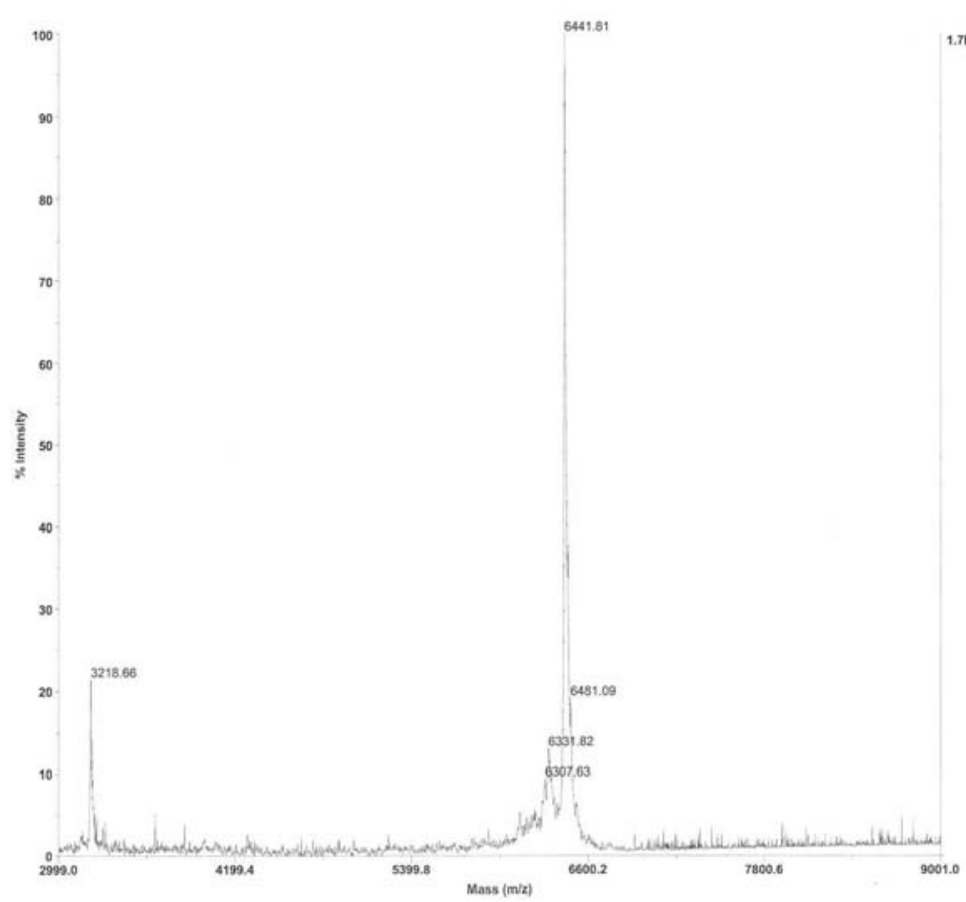

Acquirod: 16:10:00, May 17, 2010

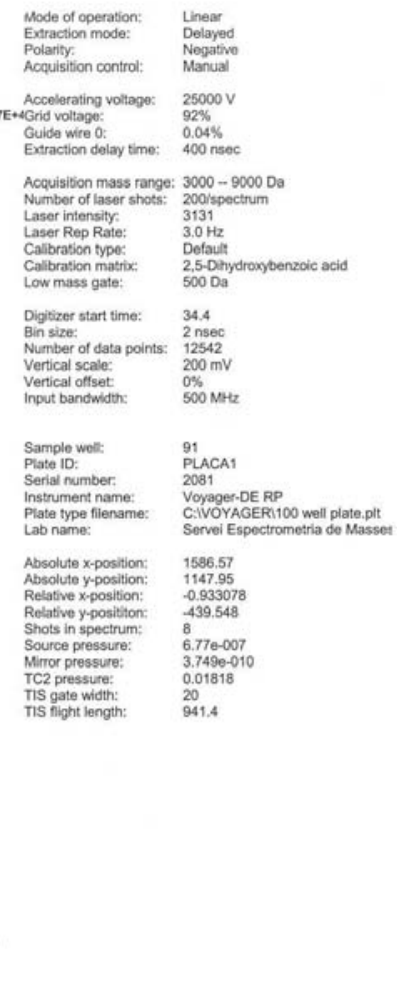

Printed: 16:11, May 17, 2010

Guide strand $\mathbf{8}$ 


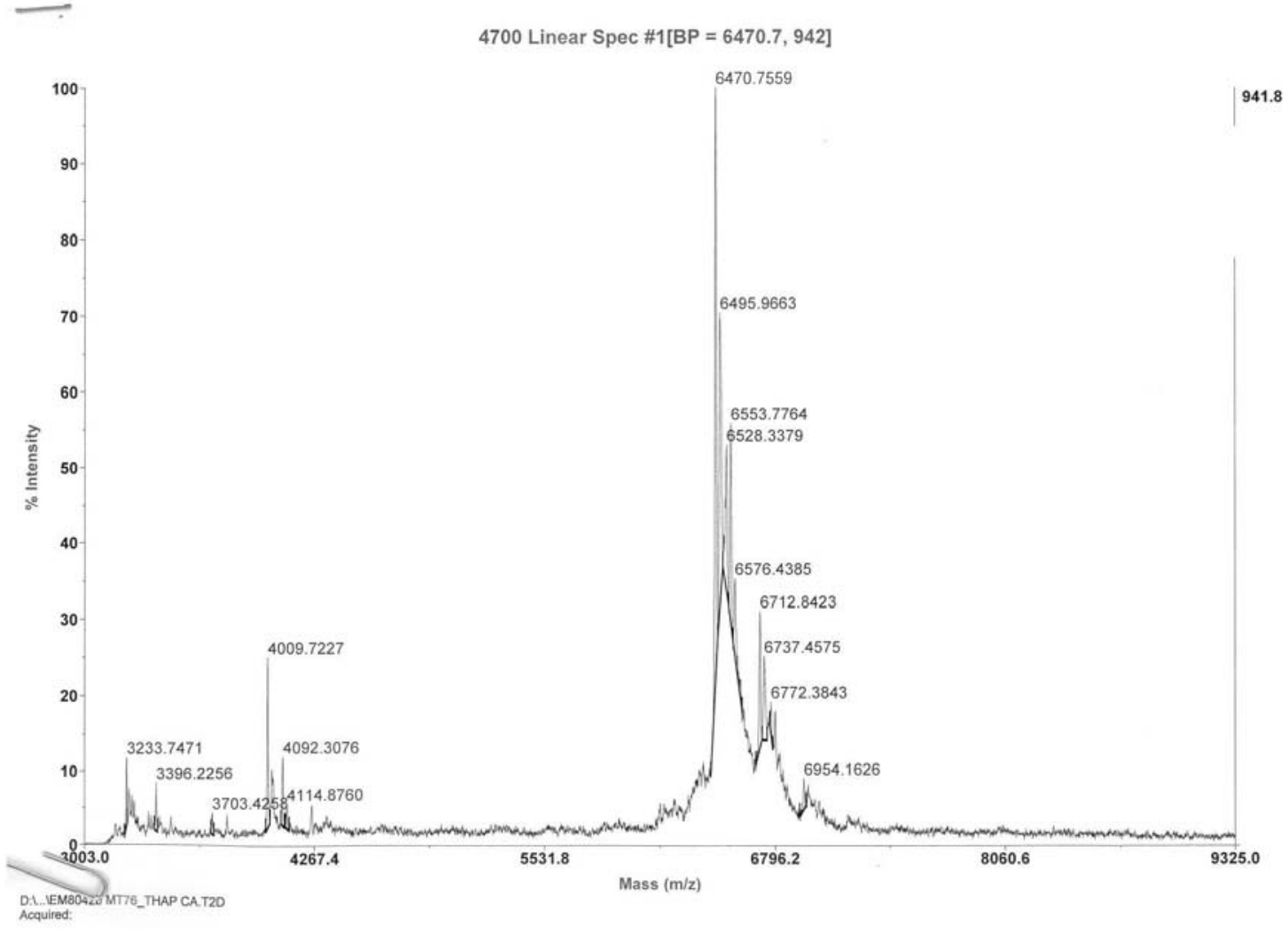

Figure S27. Plot of gene-specific RNAi activity for siRNAs formed by unmodified guide strand $\mathbf{6}$ and modified guide strands $\mathbf{7}$ and $\mathbf{8}$ expressed in 
SH-SY5Y cells

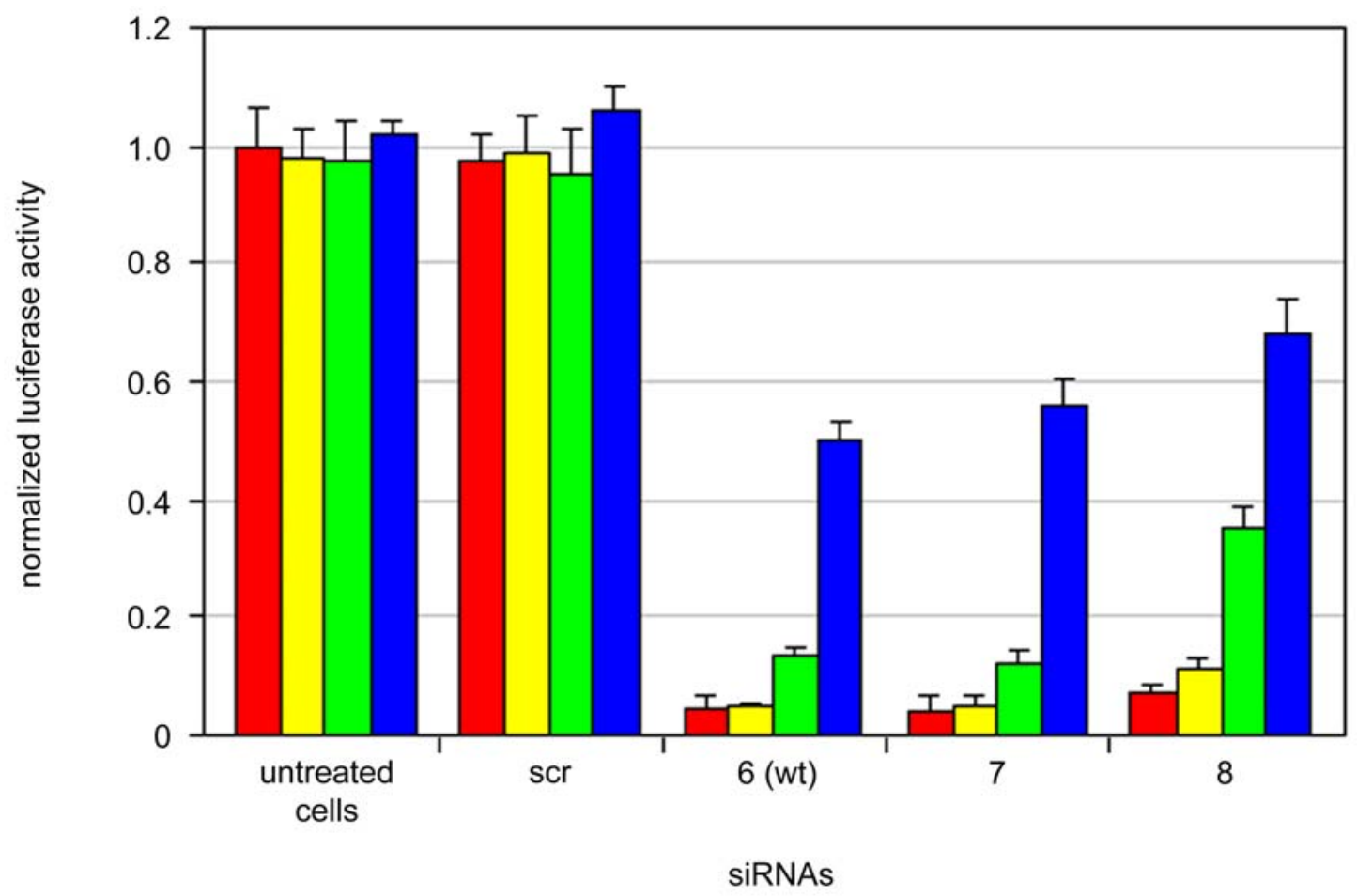

